\title{
The Law of \\ Environmental "PPMs" \\ in the WTO: Debunking the Myth of Illegality
}

\section{Steve Charnovitz ${ }^{\dagger}$}

I. INTRODUCTION

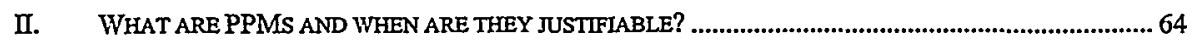

A. The Related-Unrelated Distinction ……………………...................................................... 65

B. A Taxonomy of PPMs ..................................................................................................6 67

C. Why Environmental PPMs Are Needed .................................................................................. 70

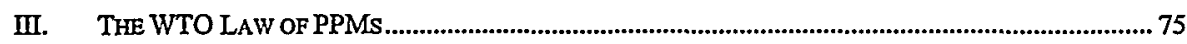

A. Structure of GATT Obligations............................................................................................ 79

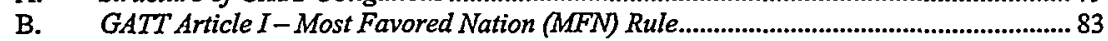

C. GATT Article III-National Treatment Rule ........................................................................ 85

D. GATT Article XX-General Exceptions ......................................................................... 92

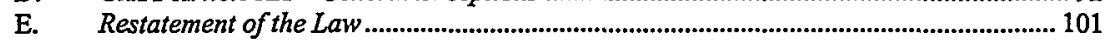

F. Broader Implications ............................................................................................................. 102

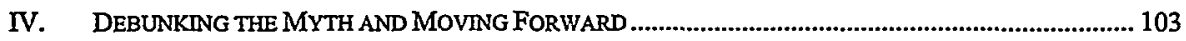

A. Disciplining PPMs ............................................................................................................. 105

B. Improving WTO Management of PPMs ..................................................................... 108

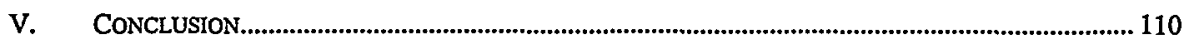

\section{INTRODUCTION}

Processes and Production Methods (PPMs) are the subject of one of the most knotty controversies in the debate over "trade and environment." At

$\dagger \quad$ Steve Chamovitz practices law at Wilmer, Cutler \& Pickering in Washington, D.C. This Article is based on a lecture delivered at the Institut Universitaire de Hautes Etudes Internationales in Geneva in October 2000. Support for this research was provided by the Ford Foundation through the Global Environment \& Trade Study at the Yale Center for Environmental Law and Policy, Yale University. Thanks to Rob Howse and Gabrielle Marceau for their helpful comments.

1. For background on the trade and environment debate, including the role of PPMs, see generally AGRICULTURE, TRADE, \& THE ENVIRONMENT (Maury E. Bredahl et al. eds., 1996); ASLAN Dragons and Green Trade (Simon S.C. Tay \& Daniel Esty eds., 1996); InTERNATIONAL Trade, INVESTMENT AND THE ENVIRONMENT (Ralf Buckley \& Clyde Wild eds., 1994); TRADE, ENVIRONMENT, AND THE MILLENNIUM (Gary P. Sampson \& W. Bradnee Chambers eds., 1999); TRADE, ENVIRONMENT aND SUSTANABLE DEVElopment: VIEWS FROM SUb-SAHARAN AFRICA AND LATIN AMERICA (Peider Könz et al. eds., 2000); TRADE, Global POLICY, AND THE ENVIRONMENT (Per G. Fredriksson ed., 1999, World Bank, Discussion Paper No. 402); DANIEL C. Esty, GReENING THE GATT (1994); JAMEs R. LeE, EXPLORING THE GAPS: VITAL LINKS BETWEEN TRADE, ENVIRONMENT, AND CULTURE (2000); ERNSTUlrich PETERSMANN, INTERNATIONAL AND EUROPEAN TRADE AND ENVIRONMENTAL LAW AFTER THE URuguay Round (1995); C. Ford RUNGe, Freer Trade, Protected ENVIRONMENT (1994); GaRy P. Sampson, Trade, Environment, and the WTO: The Post-Seattle Agenda (2000); Peter 
issue is the appropriateness of imposing trade measures contingent on the production process. ${ }^{2}$ Commentators often claim that the World Trade Organization (WTO) prohibits PPM-based restrictions affecting trade. ${ }^{3}$ Such claims have convinced many environmentalists that the WTO-led trading system interferes with ecological protection. ${ }^{4}$

The reality of international trade law is different. PPMs affecting trade are not prohibited per se. Recognizing the correct legal status of PPMs is a precondition to achieving a much needed reconciliation between the World Trade Organization and environmentalists.

One of the best known examples of a PPM-based restriction is the U.S. trade ban on shrimp from countries that have not been certified as having regulatory regimes in place to prevent the killing of sea turtles in the course of shrimping. ${ }^{5}$ The U.S. government imposed a ban on shrimp imports from countries that federal officials believed were not doing enough to prevent shrimp trawlers from killing endangered sea turtles. The enforcement of the U.S. ban led to a high-profile dispute in the World Trade Organization when

UMONEN \& JOHN WHALLEY, ENVIRONMENTAL ISSUES IN THE NEW WORLD TRADING SYSTEM (1997); DAVID VOGEL, TRADING UP: CONSUMER AND ENVIRONMENTAL REGULATION IN A GLOBAL ECONOMY (1995); RICHARD A. WESTIN, ENVIRONMENTAL TAX INITLATIVES AND MULTILATERAL TRADE AGREEMENTS: DANGEROUS COLLISIONS (1997); Special Issue: Trade and Environment, 5 ENV'T \& DEV. ECON. 341 (2000); Michael Reiterer, The International Legal Aspects of Process and Production Methods, 17 WORLD COMPETITION, June 1994, at 111.

2. The earliest analysis of such measures that has come to my attention is Theodor $E$. Gregory's tome on tariff methods published in 1921. Gregory explained that trade prohibitions could be absolute or "contingent." As examples of a contingent prohibition, he pointed to import bans on commodities produced by a government monopoly, import bans on prison-made goods, import bans on copyrighted commodities and goods with fraudulent trademarks, and import bans on goods liable to cause danger to public health. T.E. GREGORY, TARIFFs: A STUDY IN METHOD 114-15 (1921).

3. See text accompanying infra notes 83-91 for examples. The WTO is the intergovernmental organization that supervises national trade policies. The WTO became operative in 1995 as an institutional replacement for the General Agreement on Tariffs and Trade (GATT). Generally, this Article uses the word "GATT" to refer to the rules of the General Agreement on Tariffs and Trade, which have been in force (with some amendments) since 1948. General Agreement on Tariffs and Trade, Oct. 30, 1947, 61 Stat. A-11, 55 U.N.T.S. 194 [hereinafter GATT]. This agreement was incorporated into the General Agreement on Tariffs and Trade 1994 by way of paragraph 1(a) of Annex 1A of the Marrakesh Agreement Establishing the World Trade Organization, April 15, 1994 [hereinafter WTO Agreement], THE LEGAL TEXTS: THE RESULTS OF THE URUGUAY ROUND AGREEMENTS INCLUDING THE AGREEMENT ESTABLISHING THE WORLD TRADE ORGANIZATION AS SIGNED ON APRIL 15, 199417 (World Trade Organization, 1999) [hereinafter LEGAL TEXTS]. Generally, this Article uses the word "GATT" to refer to the pre-WTO trading system. For a short primer on the WTO, see Kevin C. Kennedy, The GATT-WTO System at 50, 16 WISC. INT'L L.J. 421 (1998).

4. See, e.g., HIILARY FRENCH, VANISHING BORDERS: PROTECTING THE PLANET IN THE AGE OF GlOBALIZATION 117-18, 122 (2000). French is vice president for research at the Worldwatch Institute. See also LORI WALlach \& MICHELLE SFORZA, WHOSE TRADE ORGANIZATION? CORPORATE GLOBALIZATION AND THE EROSION OF DEMOCRACY 5, 23, 28 (1999) (warning of threats posed by WTO rulings to the environment).

5. This trade ban is carried out pursuant to section 609 of the Department of Commerce, Justice, and State, the Judiciary, and Related Agencies Appropriations Act of 1990. 16 U.S.C. $\$ 1537$ (2001). Many people assume that section 609 is part of the Endangered Species Act because the codifiers placed a historical and statutory note in that part of the U.S. Code. See, e.g., Turtle Island Restoration Network v. Mallett, 110 F. Supp. 2d 1005, 1016 (Ct. Int'l Trade 2000) ("Section 609 is part of the Endangered Species Act."). This is an incorrect assumption, however, despite the obvious relationship between the goals of section 609 and the Endangered Species Act. A provision of federal law cannot become part of the Endangered Species Act unless the Congress amends the Act to put it there; the Congress has not done that in this case. 
four countries-India, Malaysia, Pakistan, and Thailand-brought a case against the United States. ${ }^{6}$ This famous WTO dispute is known as the "Shrimp-Turtle" case."

Shrimp-Turtle demonstrates the cloud of suspicion surrounding the application of PPMs. This Article argues that rather than a covert tool of protectionism, a PPM can be an appropriate instrument of environmental policy. A number of international instruments already bear witness to this fact. For example, the World Charter for Nature, approved by the United Nations General Assembly in 1982, calls on governments to "[e]stablish standards for products and manufacturing processes that may have adverse effects on nature, as well as agreed methodologies for assessing these effects." In fact, the WTO treaty acknowledges the importance of production methods for environmental policy. The WTO Agreement on Agriculture-in prescribing criteria for domestic support measures that remain exempt from reductionstates that payments under environmental programs must be dependent on specific conditions such as "conditions related to production methods or inputs." Of course, neither the World Charter for Nature nor the Agreement on Agriculture provides an explicit endorsement of a PPM affecting trade. So long as a government applies PPMs only to domestic producers, no other government is likely to complain at the WTO. Trade conflicts are likely to arise, however, upon application of a PPM to imported products or to foreign service suppliers.

With the goal of promoting the resolution of such potential trade conflicts, this Article presents a new taxonomy of PPM-based restrictions. PPMs that focus on the manner of production are preferable to PPMs that focus on the country of production. Recognizing that form matters can allow the WTO and the environmental community to communicate, thus enabling environmentalists to articulate their demands in a manner consistent with the principles of non-discriminatory trade embodied in the WTO.

Several WTO agreements already recognize the validity of PPMs that clearly affect trade. ${ }^{10}$ The Agreement on the Application of Sanitary and

6. See Bruce Neuling, The Shrimp-Turtle Case: Implications for Article XX of GATT and the Trade and Environment Debate, 22 LOYOLA L.A. INT'L \& COMP. L. REV. I (1999).

7. Notwithstanding its formal name in the WTO as "United States - Import Prohibition of Certain Shrimp and Shrimp Products," this lawsuit is widely known as the Shrimp-Turtle case. Even the WTO website uses this shorthand designation: "India etc. versus US: 'Shrimp-Turtle," available at http://www.wto.org/english/tratop_e/envir_e/edis08_e.htm. When it originally captioned the case in 1997, the WTO Secretariat missed the opportunity to demonstrate its understanding that a key issue in the case was the conservation of turtles. The WTO's name for the case reflects an assumption that the United States had been banning shrimp imports to protect its shrimping industry. In an effort to show the bias in how the WTO Secretariat styled the case, Robert Howse renames it the "Turtles panel." For his critique of the WTO panel report, see Robert Howse, The Turtles Panel: Another Environmental Disaster in Geneva, 32 J. WORLD TRADE, Oct. 1998, at 73. 459 (1983).

8. World Charter for Nature, U.N. Doc. A/RES/37/7, Nov. 9, 1982, ๆ 21(b), 22 I.L.M. 455,

9. Agreement on Agriculture, Apr. 15, 1994, WTO Agreement, Annex 1A, II (a), LEGAL TEXTS, supra note 3, at 52. Domestic support includes direct payments (or foregone revenue) provided to agricultural producers.

10. Aaron Cosbey, The WTO and PPMs: Time to Drop a Taboo, BRmGEs BETWEEN TRADE AND SUSTANABLE DEVELOPMENT, Jan.-Apr. 2001, at 11, available at http://www.ictsd.org. 
Phytosanitary Measures (SPS) states that governments shall allow a reasonable interval between the publication of a regulation and its entry into force in order to allow time for producers "to adapt their products and methods of production to the requirements of the importing Member." Agreement on Technical Barriers to Trade (TBT) has a similar provision. ${ }^{12}$ The Agreement on Trade-Related Aspects of Intellectual Property Rights (TRIPS) requires governments to establish a procedure enabling the holder of an intellectual property right to ask customs authorities to detain goods produced with a counterfeit trademark or "pirated" copyright. ${ }^{13}$ In all of these agreements, however, the foreign production process is of concern only because of its impact on the importing country.

The quarrel with PPMs is not about this kind of measure; rather, it is about the use of trade measures with an outwardly directed purpose. The U.S. import ban on shrimp was outwardly directed in that it sought to save turtles being killed hundreds or thousands of miles away. Such measures respond to the fact that activities by the nationals of one country can adversely affect the global commons.

Of course, PPMs are not always inspired by altruism. A government that has imposed a regulatory burden on its domestic producers may seek to impose a similar burden on foreign producers to keep them from gaining a competitive advantage. PPMs may also be contrived to shield domestic producers and workers from import competition. For example, a government might seek to put a special tariff on imports manufactured under lower environmental standards than a like domestic product.

The use of environmental PPMs is controversial for two main reasons. First, a PPM can restrict trade or make it harder and costlier for an exporter to supply a foreign market. Second, PPMs are a signal from importing countries to exporting countries about the environmental practices and laws that the importing country thinks the exporting country should have. The transmission of values through trade is not new and has occurred since antiquity. PPMs are different, however, because they employ government-set trade restrictions to transmit values. These two features alone would suffice to make PPMs contentious; yet the latent controversies are intensified by one further point. The user of the PPM is almost always a rich country, and the target country is often a developing country. This factor has led to the charge that environmental PPMs are a tool of eco-imperialism: the rich country may be

11. Agreement on the Application of Sanitary and Phytosanitary Measures, Apr. 15, 1994, WTO Agreement, Annex IA, LEGAL TEXTS, supra note 3 , at 68 [hereinafter SPS Agreement]. "Member" means a state or other entity that has joined the WTO. The SPS Agreement supervises government measures to protect domestic human, animal, or plant life or health from risks such as pests, disease, food additives, and toxins. For example, a measure banning the importation of anthrax spores would be governed by SPS rules.

12. Agreement on Technical Barriers to Trade, Apr. 15, 1994, WTO Agreement, Annex 1A, art. 2.12, LEGAL TEXTS, supra note 3, at 124 [hereinafter TBT Agreement]. The TBT Agreement supervises government-set product standards and promotes harmonization.

13. Agreement on Trade-Related Aspects of Intellectual Property Rights, Apr. 15, 1994, WTO Agreement, Annex 1C, art. 51, LEGAL TEXTS, supra note 3, at 344 [hereinafter TRIPS Agreement]. 
viewed as trying to coerce the poor country into placing a higher value on the environment than the poor country considers appropriate.

The international debate on PPMs is understandably heated. Both proponents and opponents of PPMs are convinced that they are right, and no compromise has emerged in the past several years. This debate is worth examining because it reflects different assumptions about what the WTO law is. A central disagreement is whether the rules of the WTO's General Agreement on Tariffs and Trade (GATT) prohibit PPMs per se, or whether they are permitted in certain circumstances. The GATT is one of the central agreements in the WTO treaty system. GATT rules supervise government restrictions on trade in goods. The GATT also contains exceptions in Article $\mathrm{XX}$ that may be used to justify environmental measures. ${ }^{14}$

This Article explicates and appraises the WTO law of PPMs. A better understanding of the law and of how PPMs operate could help governments and stakeholders improve the management of outwardly directed PPMs. Right now, governments have divergent views about WTO rules. This has led to an inside out debate from which a political consensus cannot easily emerge.

The law of PPMs received a useful clarification in October 1998 when the WTO Appellate Body handed down its decision in the Shrimp-Turtle case. ${ }^{15}$ The Appellate Body's decision seemed to imply that PPMs could be legal under the WTO. Ironically, turtles remained a flash point with the public thirteen months later when some of the anti-WTO protestors in Seattle dressed up as turtles to complain about the WTO's ruling. ${ }^{16}$ Even today, a pervasive myth exists that the WTO forbids PPMs. If this were true, it would put the WTO at odds with environmental policy. As discussed below, however, this interpretation of WTO law is flawed.

The myth that PPMs are illegal under WTO law has had three harmful consequences. First, it has fed some of the public protests against the WTO. In his careful study of trade-related environmental measures in 1995, Howard Chang warned of this danger:

\footnotetext{
The creation of barriers to environmental protection in the name of free trade has eroded respect for GATT institutions in particular and political support for free trade in general. . .. The GATT panels were understandably concemed about the potential for protectionist abuse of Article XX. Their crude but sweeping rules against trade restrictions, however, make no attempt to distinguish between legitimate environmental concerns and
}

14. GATT Article XX is discussed extensively below. For the relevant portions of Article $\mathrm{XX}$, see text accompanying infra note 99 .

15. WTO Appellate Body Report on United States Import Prohibitions of Certain Shrimp and Shrimp Products, WT/DS58/AB/R (Oct. 12, 1998), available at http://www.wto.org [hereinafter Appellate Body Shrimp-Turtle Report]. The U.S. government made the importation of shrimp contingent on whether exporting country governments had in place a regulatory program (addressing the incidental killing of sea turtles) that was comparable to the U.S. regulatory program. The Appellate Body ruled that the manner in which the law was being applied violated WTO rules because there was arbitrary and unjustifiable discrimination against the complaining governments.

16. Joan Lowy, Protesters Hove Long List of Complaints Against World Trade Group, CHATTANOOGA FREE PRESS, Dec. 2, 1999, at A7. 
protectionism, and in the process do the cause of free trade a great disservice: the political backlash against free trade may also fail to make the same distinction. ${ }^{17}$

Although the GATT jurisprudence on Article XX has improved substantially since 1995, the public is not yet aware of this development. ${ }^{18}$ Thus, the second negative effect of the myth that PPMs are illegal under WTO law is that the divergence of views on the legality of PPMs has impeded potential progress in the ongoing work of the WTO Committee on Trade and Environment. Finally, the third harmful consequence of the myth of illegality is that without a shared comprehension of the legal baseline, it is impossible to develop new disciplines to prevent inappropriate PPMs.

This Article proceeds in three parts. Part II explains what PPMs are and presents a new PPM taxonomy. It also explains why PPMs are sometimes needed for environmental management. Part III examines the relevant WTO case law on the issue of PPMs and finds that PPMs are not prohibited by the WTO. Part IV ties together Parts II and III to show how a correct legal reading may enable new integrative solutions that resolve trade and environment tensions and establish a better framework for preventing inappropriate PPMs. ${ }^{19}$

This Article focuses on environmental PPMs. Although the taxonomy can be applied to all PPMs, the legal and policy conclusions reached here are not necessarily applicable to other kinds of trade PPMs, such as labor standards or restrictions based on human rights or animal welfare. This point is noted at the start to forestall the inevitable complaint that countenancing environmental PPMs will open the door to less justifiable PPMs. ${ }^{20}$

\section{WHAT ARE PPMS AND WHEN ARE THEY JUSTIFIABLE?}

The term "processes and production methods" originated in the GATT agreement of 1979 on Technical Barriers to Trade and referred to product standards focused on the production method rather than product characteristics. ${ }^{21}$ For example, a law prohibiting the landing of fish caught using a driftnet is a PPM. ${ }^{22}$ By contrast, a law prohibiting the sale of fish

17. Howard F. Chang, An Economic Analysis of Trade Measures to Protect the Global Environment, 83 GEO. L.J. 2131, 2209 (1995). When he refers to "GATT panels," Chang means the panels appointed by the GATT as an organization before it was absorbed into the WTO in 1994.

18. See Carrie Wofford, $A$ Greener Future at the WTO: The Refinement of WTO Jurisprudence on Environmental Exceptions to GATT, 24 HARV. ENVTL. L. REV. 563, 589 (2000) (noting that activists seem unaware of the improvement in WTO jurisprudence); Michael M. Weinstein, Greens and Globalization: Declaring Defeat in the Face of Victory, N.Y. TMES, Apr. 22, 2001, §4, at 18 (contrasting developments in WTO jurisprudence with the views of the anti-WTO protestors).

19. HAROLD D. LASSWELl \& MYRES S. MCDOUGAL, 2 JURISPRUDENCE FOR A FREE SOCIETY 1050-53 (Special Edition, 1997) (discussing integrative solutions).

20. See, e.g., Magda Shahin, Trade and Environment: How Real is the Debate?, in TRADE, ENVIRONMENT, AND THE MILLENNIUM, supra note 1, at 35, 46 (expressing concern that environmental PPMs could be an opening for the enactment of PPMs aimed at improving labor standards, human rights, good governance, and all sorts of other social measures that are more properly matters for domestic political decision and have hardly any relationship with the WTO).

21. TBT Agreement, supra note 12, at 117.

22. See, e.g., Drifnet Prohibition Act $\S 8,1991$ (N.Z.), reprinted in 31 I.L.M. 214, 218, 200 (1992). U.S. law prohibits the importation of tuna from certain countries unless the exporting country 
smaller than a prescribed size is not a PPM. ${ }^{23}$ During the 1990s, the PPM concept expanded beyond product standards to embrace taxes and import bans.

\section{A. The Related-Unrelated Distinction}

Analysts often divide PPMs into two categories-product-related and non-product-related. ${ }^{24}$ Product-related PPMs are used to assure the functionality of the product, or to safeguard the consumer who uses the product. Food safety may be the best example of how regulators rely on process-based sanitary rules. ${ }^{25}$ They do so to avoid having to test the salubrity of the individual product because that could destroy its market value. Such PPMs help assure that consumers receive a product at the anticipated quality level. Thus, they are related to the product even though adherence to a particular process may not be directly detectable in the product.

By contrast, the non-product-related PPM is designed to achieve a social purpose that may or may not matter to a consumer. For example, prohibiting the use of a driftnet to catch fish may achieve an ecological goal but has no effect on a fish as such or on its nutritional and gustatory value for the consumer. Hence, such PPMs are referred to as non-product-related.

Although this related/unrelated distinction is not stated explicitly, it appears to be used in the TBT and SPS agreements. The TBT Agreement defines a covered regulation as a document which "lays down product characteristics or their related processes and production methods ...2" This would seem to suggest that TBT covers product-related PPMs and does not address other PPMs. ${ }^{27}$ SPS defines covered measures broadly and includes those referring to "processes and production methods." ${ }^{\text {"28 }}$ Yet because SPS applies only to measures seeking to protect life or health within the territory of the importing country, the typical non-product-related PPM would be excluded by this geographic limitation. ${ }^{29}$ The typical governmental measure reviewable by the SPS Agreement would be either a testable food safety

government certifies that the tuna was not harvested with a large-scale driftnet. 16 U.S.C. $\S$ 1371(a)(2)(F)(ii) (2000).

23. The United States has such a law for lobsters. 16 U.S.C. $\$ 1857(1)(J)(2000)$.

24. OECD Secretariat, Processes and Production Methods (PPMs): Conceptual Framework and Considerations on Use of PPM-Based Trade Measures, OECD/GD(97)137 (1997).

25. Linda R. Horton, Food from Developing Countries: Steps to Improve Compliance, 53 FOOD \& DRUG L.J. 139, 143-46, 158 (1998).

26. TBT Agreement, supra note 12, $\mathbb{1} 1$ (emphasis added).

27. See WTO Secretariat, Negotiating History of the Coverage of the Agreement on Technical Barriers to Trade with Regard to Labelling Requirements, Voluntary Standards, and Processes and Production Methods Unrelated to the Product Characteristics, G/TBT/W/11, IT. 131, 146 (Aug. 29, 1995).

28. SPS Agreement, supra note 11, ๆ 1 .

29. Id. I 1. It is conceivable for a non-product-related PPM to be covered by SPS. Consider a hypothetical measure forbidding the use of a pesticide in foreign agricultural production if such pesticide is to be imported from an adjoining country. Suppose that the purpose of the measure is not that the pesticide is harmful to the consumer, but that the wind blows the pesticide across the border into the importing country and hurts its agriculture. Such a non-product-related PPM would be covered by SPS. 
standard (e.g., pesticide residue) or a product-related PPM (e.g., the use of hormones in meat production).

The related/unrelated distinction is popular with commentators for its simplicity, but is flawed for that same reason. To begin with, the assertion that a PPM is unrelated to a product is too strong. Since no PPM is employed without reference to some product, categorizing it as "unrelated" or "nonrelated" is a misnomer ${ }^{30}$ Foreign processes cannot be halted at the border. As a result, preventing products from coming across the border is the only way to enforce PPM-based trade regulations.

A deeper problem is the assumption that consumer preferences can be neatly divided between the physical characteristics of the product and a bundle of other ecological or moral concerns. To be sure, the blindfolded consumer will not be able to tell whether the fish being eaten was caught using a driftnet. Yet in the real world, consumers do not have blindfolds on. Once a consumer suspects that the fish was caught with a driftnet, it may be less desirable to her. Indeed, she may not want to eat it at all. It may be impossible to convince the sovereign consumer that her concerns about unsustainable fishing practices are not physically related to the fish on her plate.

Another problem with the related/unrelated distinction is evident with regard to regulations that have multiple purposes. For example, a ban on genetically-modified food might be used to address the alleged ecological impact on agricultural production or the impact of ingestion on human health. So the same regulation can be non-product-related or product-related depending on the purpose for which it was enacted.

Still another difficulty is that for some PPMs the process is the product. The best example is a regulation specifying a minimum amount of recycled content. Such a regulation defines the product and also mandates a production process that uses recycled inputs. Yet recycled newsprint may be indistinguishable from virgin newsprint and will be used in the same way by the consumer. ${ }^{31}$

Notwithstanding these conceptual dilemmas, this Article will follow the practice of categorizing PPMs as being either product-related or non-productrelated. The Article does so because this distinction is a central part of the contemporary debate. The focus in what follows will be on non-productrelated environmental PPMs. Generalizing about non-product-related PPMs can be misleading because not all PPMs are equal. The next section will introduce a taxonomy to clarify the variety of ways in which PPMs operate. ${ }^{32}$ The debate on PPMs has made little progress in ten years because it conflates too many different types of measures.

30. Arthur E. Appleton, Telecommumications Trade: Reach Out and Touch Someone?, 19 U. PA. J. INT'L ECON. L. 209, 216 (1998).

31. See J. Christopher Thomas, The Future: The Impact of Environmental Regulations on Trade, 18 CAN.-U.S. L. J. 383, 389-90 (1992) (discussing the recycled newsprint standard).

32. This framework could also be applied to product-related PPMs. 
B. A Taxonomy of PPMs

A better appreciation of the differences between various PPMs can improve the tenor of the debate and lay a foundation for an international consensus. To that end, this Article presents a taxonomy of PPMs distinguishing three distinct types: (1) the how-produced standard, (2) the government policy standard, and (3) the producer characteristics standard. A how-produced standard specifies the processing method used for making the product. For example, a law banning the importation of driftnet-caught fish is a how-produced PPM. A government policy standard specifies laws or regulations of a foreign government regarding the production process, or its enforcement of them. For instance, a law banning the importation of fish from any country that permits driftnet fishing is a government policy PPM. Such PPMs focus on the methods used for mining, harvesting, manufacturing, packaging, or transporting. These PPMs can be contrasted to an import ban that has no connection to production methods. For example, a trade measure directed at "widget" imports to induce another country to stop driftnet fishing is not a PPM. ${ }^{33}$

A standard that hinges on the identity of the producer or importer is not always viewed as a PPM. For example, a law that bans fish imports from a producer owned by a pariah government will probably be considered a plain embargo rather than a PPM. Nevertheless, the PPM analyst will want to take account of the producer characteristics standard for at least two reasons. First, in specifying attributes of a producer or its contractual relations, the importing government can seek to accomplish policy purposes similar to what might be sought using a how-produced or a government policy PPM. Second, much of the relevant trade law jurisprudence involves measures based on producer characteristics. Therefore, such measures will be treated here as PPMs.

This Article uses the term "standard" to mean a product specification that is legally required. This usage differs from that in the TBT Agreement, where "standard" means product characteristics or product-related PPMs with which compliance is not mandatory. ${ }^{34}$ While the TBT Agreement uses the term "regulation" for "mandatory" provisions, the taxonomy laid out in this Article uses the term "standard" rather than "regulation" for two reasons: first, while some environmental PPMs are regulations applied equally to foreign and domestic products, many PPMs are import bans that may not come within the scope of TBT:35 second, the term "regulation" has a connotation of jurisdiction to prescribe individual behavior that does not fit PPMs, which set conditions for entry or sale that the exporter may or may not seek to meet. If

33. U.S. law bans the importation (in certain circumstances) of sport-fishing equipment from countries whose governments have not agreed to terminate large-scale driftnet fishing by nationals beyond the exclusive economic zone. 16 U.S.C. § 1826a (1988). This is not a PPM as defined here. Rather, it is a trade sanction. For another example of an environmental trade sanction, see 19 U.S.C. $\S$ 1323 (1994).

34. TBT Agreement, supra note 12, Annex $1, \llbracket 2$.

35. See id. ๆ 1. 
the exporter does not meet these conditions, no disadvantage is incurred other than an inability to sell to the PPM-applying country.

A standard prescribing where a product must be produced is not a PPM. For example, the U.S. law that bans fish (and all other) imports from Cuba is a plain embargo rather than a PPM. ${ }^{36} \mathrm{~A}$ where-produced standard can sometimes be disguised as a how-produced standard by using origin-neutral language that pertains only to a particular country. Probably the most wellknown PPM in the history of trade policy was the German law of 1904 providing a tariff reduction for "large dappled mountain cattle or brown cattle reared at a spot at least 300 meters above sea level and which have at least one month's grazing each year at a spot at least 800 meters above sea level. ${ }^{237}$ That is a how-produced PPM that is non-product-related. Germany apparently wanted to give a trade concession to Switzerland without generalizing it to other countries with whom it had trade agreements. ${ }^{38}$ This cattle PPM is the classic example of the way in which a discriminatory tariff preference can be disguised as a how-produced standard.

Although this Article looks at environmental PPMs, the suggested taxonomy applies to other PPMs too. For example, in July 2000, the World Diamond Congress pressed for action to combat trade in "conflict diamonds" that are used to fund terrorism in Africa ${ }^{39}$ The Congress urged an import ban on diamonds from countries that have not passed redline legislation requiring diamonds to be sealed and registered. Such a ban would be a government policy standard. In January 2001, President Clinton issued an Executive Order to prohibit the importation of rough diamonds from Sierra Leone unless the particular diamond was controlled through a certificate of origin from the Government of Sierra Leone. ${ }^{40}$ This is a how-produced (or who-produced) PPM that treats like diamonds differently based on who mines and cuts them.

In presenting this PPM taxonomy, this Article argues that form matters and that how-produced standards are preferable to government policy and producer characteristics standards. In Part III, the Article will show that a how-produced standard may be less likely to violate WTO rules than the other two types of PPMs.

The government policy standard has four major faults. ${ }^{41}$ First, it is coercive in that it dictates environmental policies to foreign governments.

36. 22 U.S.C. $\S 6032(\mathrm{~h})(2001)$.

37. Memorandum on Discriminatory Tariff Classifications, League of Nations Doc. C.E.C.P. 96 , at $8(1927)$.

38. Robert E. Hudec, "Like Product": The Differences in Meaning in GATT Articles I and III, in REGULATORY BARRIERS AND THE PRINCIPLE OF NON-DISCRIMINATION IN WORLD TRADE LAW 101, 109-11 (Thomas Cottier \& Petros C. Mavroidis eds., 2000).

39. Holly Burkhalter, Deadly Diamond, LeGAL TMEES, Sept. 11, 2000, at 74; Andrew Parker, Pledge on Move to Curb "Conflict Diamond" Sales, Fin. TMMEs, Oct. 27, 2000, at 16. For recent developments see Nicole Itano, Countries Near Agreement on process for Certification to Curb 'Blood Diamonds,' BNA DALY REPORT FOR EXECUTIVES, Nov. 8, 2001, at A21.

40. Exec. Order No. 13,194, 66 Fed. Reg. 7,389 (Jan. 23, 2001).

41. It is interesting to note that in 1927, the Swedish delegation to the World Economic Conference pointed out that the most-favored-nation principle might be evaded by an unfounded distinction such as the "measures taken by the authorities of the exporting State." Report and Proceedings of the World Economic Conference, League of Nations Doc. C.356.M.129.1927.II, at 236 
Second, this standard penalizes a private economic actor who may be doing everything right from an environmental perspective, but whose exports remain blocked because its good environmental behavior is not mandated by its nation's law. Third, the government policy standard is unfair because it is more available to large than to small countries. ${ }^{42}$ Fourth, the government policy standard can lead to conflict because two importing countries might impose inconsistent policy standards on an exporting country.

By contrast, the how-produced standard operates much like a simple product standard. ${ }^{43}$ It does not coerce governments, nor does it penalize economic actors who are willing to assure that their exports meet the importing country's standard. Moreover, small countries can use howproduced standards because they will almost always find willing suppliers. For these reasons, the how-produced standard will probably not cause as much trade tension as the government policy standard does.

The how-produced standard can be a proportionate and measured response to a situation where importing from the other country can exacerbate an environmental problem. For example, when a government allows the importation of fish caught with a driftnet, the importing country signals that such odious practices are acceptable for future trade, and so exporting country producers may continue to use them. On the other hand when a government bans such fish imports, it signals its objections to that method of production and may make it less profitable. ${ }^{44}$ Private economic actors will then have a new incentive to modify their environmental behavior.

A how-produced PPM could be less effective than a government policy standard and that could be unsatisfactory to environmental regulators. ${ }^{45}$ But this lower effectiveness needs to be balanced against the disadvantages of being heavy-handed from the point of view of environmental policy. It is one thing for Country I to specify a PPM for the fish that it imports from Country E. It is quite another for Country I to say that it will not import any fish from $E$ unless all of E's fish catch are caught in the prescribed way. Treating Country E unfairly may make it harder to convince E's government and stakeholders to cooperate on environmental protection matters.

This section has developed categories of PPMs with two purposes in mind. One is to show how PPMs influence behavior. This can be useful in designing and implementing PPMs. The other purpose is to draw upon these categories in explicating WTO law in Part III. The PPM taxonomy will be helpful in seeing how WTO law has evolved and where it might be going.

(1927). Thus, concerns about the government policy standard go back to one of the earliest international conferences on trade policy.

42. In order for a government policy standard to influence a foreign government, the standard-writing country must purchase a large share of the target production. As the world's largest importer, the United States is also the most frequent user of government policy standards.

43. Joanne Scott, On Kith and Kin (and Crustaceans): Trade and Environment in the EU and WTO, in THE EU, THE WTO, AND THE NAFTA: TOWARDS A COMMONLAW OF INIERNATIONAI TRADE? 139 (J.H.H. Weiler ed., Ist ed. 2000).

44. Robert Howse \& Donald Regan, The Product/Process Distinction - An Illusory Basis for Disciplining "Unilateralism" in Trade Policy, 11 EUR. J. INT'L L. 249, 272-73 (2000).

45. Chang, supra note 17 , at $2177-85$. 
Before moving to Part III, however, the Article will explain why environmental PPMs are needed for environmental protection.

\section{Why Environmental PPMs Are Needed}

Non-product-related PPMs are a response to humankind's shared habitation on the planet. The driftnet fishing example is just one of a wide array of concerns that consumers may have about the side effects of production. Various terms are used to describe this concern, such as the "environmental profile" of a product or its "ecological footprint." Citizens and consumers have these concerns because the public in one country can be affected by the production methods used in another.

While it is easy to criticize PPMs as a manifestation of eco-imperialism, that characterization is too simplistic. PPMs are a symptom of the dysfunctions in international environmental governance. Among the biggest problems are poor stewardship of the global commons, lack of liability for transboundary environmental harms, and free riding in treaties. PPMs are an inevitable response to the disagreements between countries at different stages of development. Addressing these root causes would not only obviate many PPMs, but could also improve prospects for economic growth and environmental protection.

PPMs have always been a feature of environmental law. For example, in 1906, the U.S. Congress passed a law banning the landing of sponges taken by means of a diving apparatus from the waters of the Gulf of Mexico. ${ }^{46}$ The diving techniques at issue were destructive of the sponge bed, as compared to the use of simple hooks. Another example comes from 1925, when a treaty between Mexico and the United States set up an International Fisheries Commission to conserve marine life in the Pacific Ocean. The treaty committed the parties to refuse the landing of any fish taken in violation of the Commission's regulations. ${ }^{47}$ This treaty is noteworthy in demonstrating the early acceptance by Mexico of the application of PPMs to imported fish. Another early example of a trade PPM occurred in the 1931 treaty between Denmark and Sweden to protect migratory birds. This treaty forbade the use of nets for catching seabirds and prohibited the sale or transport of such birds when caught in nets. ${ }^{48}$

Even when a treaty is in place, a government may use unilateral trade measures to seek to enhance the treaty's effectiveness. For instance, in 1950 the United States enacted a law prohibiting the import of whale products taken

46. An Act To Regulate the Landing, Delivery, Cure, and Sale of Sponges, ch. 3442, 34 Stat. 313 (1906) (repealed 1914). The Act had an exception for sponges taken in deep water between October and May. The application of this Act to foreign commerce was held constitutional in The Abby Dodge, 223 U.S. 166, 176-77 (1912).

47. Convention to Prevent Smuggling and for Certain Other Objects, Dec. 23, 1925, U.S.Mex., arts. 10-12, 48 L.N.T.S. 444 (no longer in force).

48. Agreement regarding certain provisions for the Protection of Migratory Game-Birds, Oct. 9, 1931, Den.-Swed., art. 2, 126 L.N.T.S. 259. 
in violation of the Whaling Convention. ${ }^{49}$ The Whaling Convention itself did not provide for the use of trade measures as a means of enforcement. ${ }^{\text {so }}$

Because many important international environmental treaties have been developed during the past three decades, there is sometimes a tendency to assume that any significant transborder environmental problem will lead to a treaty that averts the need for unilateral PPMs. Throughout the 1990s this belief was a common theme in the criticism of PPMs, which assumed that countries like the United States were choosing national action over equally available multilateral action. ${ }^{51}$ But the reality is that effective, broadmembership treaties are difficult to achieve. ${ }^{52}$ Furthermore, treatymaking negotiations sometimes succeed because leading countries have manifested a willingness to act alone if necessary, a process called "policy-forging" unilateralism by Laurence Boisson de Chazournes. ${ }^{33}$

In their introductory essay to The Greening of World Trade Issues in 1992, Kym Anderson and Richard Blackhurst framed the issue properly. They said that "[i]f all countries participated in all international environmental agreements, there would be nothing more to add. ${ }^{354}$ Yet as Anderson and Blackhurst acknowledge in that seminal volume, many environmental problems are not addressed by treaties with sufficient country membership and compliance. .5

The protection of migratory sea turtles is an example of a longrecognized problem for which international legislation emerged slowly. As early as 1924, the Pan-Pacific Food Conservation Conference warned that

49. 16 U.S.C. $\$ 916 c(a)(1994)$.

50. International Convention for the Regulation of Whaling with Schedule of Whaling Regulations, Dec. 2, 1946, 161 U.N.T.S. 72.

51. GATT Secretariat, Trade and the Environment, 1 INIERNATIONAL TRADE 90-91, at 2325, 35-36 (1992).

52. The earliest analysis of the difficulty in attaining an environmental treaty that has come to my attention is Charles Edward Fryer, International Regulation of the Fisheries of the High Seas, 28 BULL. OF THE BUREAU OF FISHERIES 91 (1908). Fryer explains that "two nations whose fishermen practice different methods of fishing for the same kind of fish will not always admit that the same necessity exists for its protection or that the remedy is the appropriate one." Id. at 95 . For more recent discussions of the difficulties governments sometimes have in achieving environmental agreements, see PETER H. SAND, LEsSONS LEARNED IN Global ENVIRONMENTAL GoverNance 5-14 (1990); LAWRENCE E. SUSSKIND, ENVIRONMENTAL DIPLOMACY 11-42 (1994); Richard Blackhurst \& Arvind Subramanian, Promoting Multilateral Cooperation on the Environment, in THE GREENING OF WORLD TRADE ISSUES 247, 247-60 (Kym Anderson \& Richard Blackhurst eds., 1992). A current example of the difficulty of achieving an environmental agreement is the negotiations to improve the Kyoto Protocol on climate change so that more governments will ratify it, thereby raising the number of governments ratifying the Protocol beyond the current number of 40 . See also Kal Raustiala, Compliance and Effectiveness in International Regulatory Cooperation, 32 CASE W. RES. J. INT'L L. 387, 392-94 (discussing the relationship among compliance, implementation, and effectiveness of international regulatory cooperation).

53. Laurence Boisson de Chazournes, Unilateralism and Environmental Protection: Issues of Perception and Reality of Issues, 11 EUR. J. INT'L L. 315, 317, 325 (2000). In policy-forging unilateralism, the author of the measure uses it to reshape a legal regime. De Chazournes lists several examples from the history of environmental policymaking, the earliest being the Russian decree of 1893 to forbid the hunting of fur seals just outside Russian territorial waters. Id. at 332 .

54. Kym Anderson \& Richard Blackhurst, Trade, the Environment and Public Policy, in THE GREENING OF WORID TRADE ISSUES, supra note 52, at 3, 20.

55. See generally id. 
"action is necessary to save the marine turtles of various countries from commercial, if not actual extinction." ${ }^{356}$ In 1979, the World Conference on Sea Turtle Conservation called for international and national fishery commissions to "promulgate regulations requiring the use of gear which precludes the capture of sea turtles ..." and for the U.N. Environment Programme and the Food and Agriculture Organization to make U.S. technology for turtle-safe shrimping available to world fishing fleets. ${ }^{57}$ In 1989, the U.S. Congress directed the Secretary of State to initiate negotiations as soon as possible with all foreign governments who have nationals engaged in commercial fishing that may adversely affect sea turtles. ${ }^{58}$ Yet it was not until 1996 that governments succeeded in negotiating the first treaty on sea turtle conservation, and this did not occur until after the U.S. government had banned shrimp from countries whose vessels were not using turtle excluder devices (TEDs). ${ }^{59}$

Recently, the U.N. Food and Agriculture Organization's Committee on Fisheries gave a qualified endorsement to trade PPMs. The Committee recommended that governments consider using trade PPMs to address "illegal, unreported and unregulated" (IUU) fishing in world fisheries. Specifically, the Committee stated:

States should take all steps necessary, consistent with international law, to prevent fish caught by vessels identified by the relevant regional fisheries management organization to have been engaged in IUU fishing [from] being traded or imported into their territories. . . . Trade-related measures should be adopted and implemented in accordance with international law, including principles, rights and obligations established in WTO Agreements, and implemented in a fair, transparent and non-discriminatory manner. . . Unilateral trade-related measures should be avoided. ${ }^{60}$

If other instruments were immediately available to deter harmful fishing, the Committee probably would not have endorsed controversial trade measures.

Of course, environmental negotiations will not always need the fillip of threatened trade measures. Most environmental treaties were achieved without any inducement by trade measures. Yet trade measures can sometimes be useful to address the problem of free riders. ${ }^{61}$ For example, the Montreal Protocol on Ozone prohibits trade in controlled substances with non-parties (unless they are in full compliance with the Protocol's control measures). ${ }^{62}$

56. 29 MID-PAC. MAG. 182, 183 (Jan. 1925).

57. BIOLOGY AND CONSERVATION OF SEA TURTLES, Proceedings of the World Conference on Sea Turtle Conservation 582 (Karen A. Bjorndal ed., 1981).

58. Departments of Commerce, Justice, and State, the Judiciary, and Related Agencies Appropriations Act of 1990, Pub. L. No. 101-162, § 609(a)(2), 103 Stat. 1037 (1990).

59. Inter-American Convention for the Protection and Conservation of Sea Turtles, Dec. 1 , 1996, S. TREATY DOC. No. 105-48, (1998), available at http://www.seaturtle.org/iac. The import bans on shrimp began in 1991. U.S. Customs Service Memorandum Regarding Importations of Shrimp from Suriname, May 2, 1991. The turtle excluder device (TED) is a trapdoor installed inside a trawling net that allows shrimp to pass to the back of the net while directing sea turtles out of the net.

60. International Plan of Action to Prevent, Deter and Eliminate Illegal, Unreported and Unregulated Fishing, If 66 (June 23, 2001), available at http://www.fao.org/fi.

61. Jennifer A. Bernazani, The Eagle, The Turtle, The Shrimp and the WTO: Implications for the Future of Environmental Trade Measures, 15 CONN. J. INT'L L. 207, 211-12 (2000).

62. Montreal Protocol on Substances that Deplete the Ozone Layer, Sept. 16, 1987, 26 I.L.M. 
This trade provision is considered to be an important factor in eliciting the wide membership of this treaty. ${ }^{63}$ Another example is dolphin conservation. Research by Richard Parker shows that the threat of trade leverage was crucial to getting a dolphin conservation program started in the Inter-American Tropical Tuna Commission. ${ }^{64}$

When the first-best option of multilateral cooperation is unavailable, an affected government may consider using a trade PPM to address transborder problems indirectly. Precisely because it is so indirect, such a PPM may be inefficient. Yet the most efficient measures are only available to a government with prescriptive jurisdiction over the environmentally damaging process. So if the producing country's government fails to use its own direct regulatory instruments, other affected country governments will be left with less efficient instruments.

In deciding whether to use such a PPM, a government may consider not only the consequential impact but also the demonstration effect of acting to address an environmental problem. One early recognition of the value of setting a good example involved bird hunting. In the early twentieth century, millions of birds were being killed for their plumage. ${ }^{65}$ Bird protection groups in Great Britain sought a ban on feather imports, but the ban was opposed on the grounds that this solitary action would be insufficient to effectuate bird preservation. One essayist responded in 1909 to this claim by saying:

[I]f the importation into our country is stopped, other Governments may follow suit. Representations to foreign countries are much more likely to be effectual if made by a Government which has had the courage of its convictions, and has already put its principles into practice. 66

By 1914, Great Britain took action to ban the importation of certain types of bird plumage. ${ }^{67}$ Similar action in other countries reduced traffic in birds and led to changes in fashion that reduced demand for feathers. ${ }^{68}$

A close analysis of the main anti-PPM argument shows that it leads to untenable conclusions. Some commentators say that an environmental PPM is wrong because it seeks to force changes in practices occurring in foreign countries. Yet if that were true, it would also be true for product-related PPMs such as meat safety rules, which work by eliciting changes in production practices in other countries. ${ }^{69}$ The same concern would also apply to simple

1550 , and as adjusted thereafter, art. 4, available at http://www.unep.org/ozone/mont_thtm.

63. DUNCAN BRACK, INTERNATIONAL TRADE AND THE MONTREAL PROTOCOL 54-58 (1996); ORganisation FOR ECONOMIC CO-OPERATION AND DEVELOPMENT, TRADE MEASURES IN MULTILATERAL ENVIRONMENTAL AGREEMENTS 80-81 (1999). 25 (2001).

64. Richard Parker, The Case for Environmental Trade Sanctions, 7 WIDENER L. SYMP. J. 21,

65. Joseph Kastner, Long Before Furs, It Was Feathers that Stirred Reformist Ire, SMTTHSONIAN, July 1994, at 96.

66. A. HOLTE MACPHERSON, LEgiSLATION FOR THE PROTECTION OF BIRDS 29 (1909).

67. An Act to amend the Customs Tariff, 4 \& 5 Geo. 5, c. 3 (1907) (Eng.).

68. See generally ROBIN W. DOUGHTY, FEATHER FASHIONS AND BIRD PRESERVATION (1975).

69. David M. Driesen, What is Free Trade?: The Real Issue Lurking Behind the Trade and Environment Debate, 41 VA. J. INT'L L. 279, 311, 343 (2001). 
product standards, such as automobile safety requirements, that regularly induce foreign manufacturers to adapt their assembly lines. ${ }^{70}$ The WTO Agreement itself contains thirty-three pages of textile tariff classifications, and these minor differences may encourage producers to design their products to meet one standard rather than the other. ${ }^{11}$ Since such normal standard-setting cannot possibly be prohibited by WTO rules, the initial premise that WTO rules prohibit standard-setting that seeks to change foreign manufacturing practice must be faulty. The fact that a government regulation in Country I will induce businesses in Country $\mathrm{E}$ to change their behavior does not render I's regulation illegitimate under WTO rules.

Of course, any PPM-product-related or not-should be subjected to scrutiny by the WTO to determine whether it is protectionist. ${ }^{72}$ The key question to ask is whether the importing country government has a solid environmental rationale for being concerned about production practices in the exporting country. The fact that domestic producers might want foreign producers to be subject to the same environmental PPM may be a warning signal of protectionist intent but is not itself conclusive. In many instances, the importing country will have an environmental reason to want other countries to take comparable action to safeguard a shared natural resource.

Because environmental PPMs are typically employed to correct market failure, they increase global economic efficiency when well-designed. ${ }^{73}$ Not every country will necessarily be better off as a result, however. Trade measures taken for environmental purposes can cause adverse economic effects on exporting countries. When such exporting countries are less developed, PPMs could easily exacerbate global income inequities.

Policymakers using PPMs ought to be sensitive to how much of the financial burden for ecological protection is being shifted. More examination is needed of the costs imposed by PPMs on less developed countries. When the environmental benefits of a PPM accrue to the entire world, the costs should be borne primarily by the richer countries, which should either pay

70. For example, the U.S. government will soon require that car trunks have inside releases. Passenger Cars Must Have Trunk Releases To Avoid Entrapment Under New Standard, BNA DAlly REP. FOR EXECUTTVES, Oct. 18, 2000, at A36. This new standard will surely force foreign automakers to redesign their products.

71. WTO Agreement on Textiles and Clothing, Annex, Apr. 15, 1994, WTO Agreement, Annex 1A, LEGAL TEXTS, supra note 3, at 85. Some of these categories read like PPMs (e.g., 5702.10).

72. Daniel P. Blank, Target-Based Environmental Trade Measures: $A$ Proposal for the New WTO Committee on Trade and Environment, 15 STAN. ENVTL. L.J. 61, 119 (1996).

73. For example, in the shrimp-turtle controversy, a minor change in shrimping practices was needed to safeguard sea turtles. If turtles are appropriately valued at zero, then changing the practices would decrease global output. On the other hand, with any reasonable valuation, the cost of saving the sea turtle is worth the added fishing cost of using a turtle excluder device. In the beginning, the shrimpturtle clash may have resulted from different valuations placed on turtles, but by the time the dispute got to the WTO, all of the complaining governments were carrying out programs to protect turtles. What was disputed was whether the United States had an obligation under trade rules to allow in all shrimp regardless of whether turtles were being killed-in other words, whether any PPM was WTO-legal. The plaintiff countries were not arguing that turtles were unworthy of protection. Their argument was that the United States was keeping out more shrimp than was warranted because of a badly designed import ban. Indeed, one of the plaintiffs, Thailand, had already implemented a sufficient conservation program to meet the U.S. requirements and was exporting shrimp to the United States. 
more for the good in question, ${ }^{74}$ or provide financial or technology transfers to poor societies to enable them to efficiently comply with the PPM requirement. Current mechanisms do not provide for fair burden sharing.

In summary, Part II explains why trade measures are sometimes needed and presents the author's taxonomy of PPMs. The government policy standard is contrasted with the how-produced standard, and the latter is shown to be a better approach. Governments use environmental PPMs in treaties and national law in order to achieve conservation or anti-pollution goals. PPMs aimed at foreign governments are indirect, and thus are often blunt tools. Nevertheless, resort to such PPMs may be better than doing nothing in the absence of multilateral cooperation.

\section{THE WTO LAW OF PPMS}

Part III analyzes how WTO rules supervise PPMs applied to imports. If a WTO Member government believes that a PPM in another WTO Member country violates trade rules, the complaining government may raise the issue in WTO dispute settlement. ${ }^{75}$ A three-person panel will be appointed, which will review briefs, hold oral hearings, and issue a decision in about six months. ${ }^{76}$ This panel's decision may be appealed by either a plaintiff government or the defendant government to the WTO Appellate Body, which assigns three of its jurists to hear the appeal and issues a final ruling in about sixty days. The Appellate Body may uphold, modify, or reverse the legal findings and conclusions of the panel. ${ }^{n}$ The reports of the panel and the Appellate Body are then automatically adopted by the WTO Dispute Settlement Body, which consists of delegates of all of the WTO Member countries. ${ }^{78}$ At that point, defendant governments are under a treaty obligation to comply promptly. ${ }^{79}$ Of course, the drafters of the WTO recognized the

74. Generally one would assume that if U.S. law imposes a PPM on the harvesting of shrimp, then the cost of meeting that PPM would be paid for by the consumers of shrimp in the United States. In other words, the producers of shrimp in the United States and the exporters of shrimp to the United States would be able to pass on the added costs of turtle safety to consumers. It is possible for the foreign supplier to be put at a competitive disadvantage if the technology of safeguarding turtles is more costly in the developing country than in the United States.

75. Understanding on Rules and Procedures Governing the Settlement of Disputes [hereinafter DSU], Apr. 15, 1994, WTO Agreement, Annex 2, art. 3, LEGAL TEXTS, supra note 3, at 355. 76. Id. arts. 6-18.

77. Id. art. 17.

78. Id. arts. 16.4, 17.14. In the GATT, panel reports were recommendations to the governments that had to be adopted by the GATT Council in order to give life to these judicial decisions. The same practice continues in the WTO, but the decision rule has been changed to provide for adoption unless all governments disagree. The underlying idea is that a panel cannot tell governments what to do. The governments (including the defendant government) themselves transform the panel's decision into "law" by adopting it. It is possible for the Dispute Settlement Body to decide by consensus not to adopt a report, but this has never happened. For this to occur, the government winning the dispute would have to join a consensus to put aside its victory. In one instance in the banana dispute, a compliance panel report was not adopted because neither party put the question of adoption on the Body's agenda.

79. Id. art. 21.1 (stating that prompt compliance is essential). In addition, the DSU states that Appellate Body reports shall be adopted by the Dispute Settlement Body and "unconditionally accepted by the parties to the dispute." Id. art. 17.14. In a recent DSU Article 21.3 arbitration to set the reasonable 
possibility that a government might not comply and that the WTO (or a winning plaintiff) has no way to compel compliance by seeking court orders within the defendant government's national legal system. In an effort to induce compliance, the WTO rules provide for trade retaliation by a winning plaintiff government against a non-complying defendant government. ${ }^{80}$ The experience so far demonstrates a good record of compliance. ${ }^{81}$

Many commentators contend that WTO rules do not permit importing governments to make distinctions based on the production process. The quotations below demonstrate how widespread the view is that PPMs are illegal under trade rules. ${ }^{82}$ This list is balanced in containing commentators who favor the WTO's anti-PPM stance and those who oppose it.

This [shrimp] ban was a unilateral trade measure, in clear contradiction of the WTO principle that production and processing methods are not valid reasons for product differentiation. ${ }^{83}$ (Maria Amparo Albán, Ecuadorean Centre for Environmental Law, 1998.)

The traditional understanding of the provisions of the GATT is that they recognize only the physical characteristics of a product, not how it is made. There is a sound economic reason for this. ${ }^{84}$ (Alan Oxley, Former Ambassador of Australia to the GATT, 1999.)

GATT rules require that imported and domestically produced goods be treated equally and that foreign goods not be subject to import restrictions on the basis of "production processes and methods"-PPMs-used in their manufacture. ${ }^{85}$ (I.M. Destler \& Peter J. Balint, Institute for International Economics, 1999.)

period of time for implementing a panel report, Appellate Body Member Florentino P. Feliciano explained, "Implementation, in essence, consists of bringing the measure held to be inconsistent with the obligations of the WTO Member concerned under particular provisions of a particular covered agreement, into conformity with those same provisions." Award of the Arbitrator, Argentina - Measures Affecting the Export of Bovine Hides and the Import of Finished Leather, Arbitration under Article 21.3(c) of the Understanding on Rules and Procedures Governing the Settlement of Disputes, WT/DS155/10, ๆ 40 (Aug. 31, 2001), available at http://www.wto.org (emphasis added). The decision granted Argentina a little over a year to correct its WTO violation. See also Christine Gray, Types of Remedies in ICJ Cases: Lessons for the WTO?, in IMPROVING WTO DISPUIE SETTLEMENT PROCEDURES: ISSUES AND LESSONS FROM THE PRACTICE OF OTHER INTERNATIONAL COURTS AND TRIBUNALS 401, 411 (Friedl Weiss ed., 2000) (contending that once a WTO case has been decided, the option to pay compensation rather than comply is no longer lawfully available under WTO rules).

80. DSU, supra note 75, art. 22.6. Because of this possibility of retaliation, WTO decisions are sometimes viewed as more binding than many other decisions rendered by international courts or tribunals.

81. WORLD TRADE ORGANIZATION, Update of WTO Dispute Settlement Cases, November 7, 2001, WT/DS/OV/2, available at http://www.wto.org.

82. Not all commentators were so quick to assume that PPMs violate GATT rules. In his treatise of 1989, John Jackson suggests that the Article XX exceptions imply a focus on the product itself, and not on the production process. But he goes on to add that it might be possible to argue the contrary, and that the issue has not been squarely posed in dispute settlement. JOHN JACKSON, THE WORLD TRADING SYSTEM 209 (Paperback Edition, 1992). It should be noted that many trade law analysts have stated that PPMs are legal under WTO rules.

83. Maria Amparo Albán, Trading Sovereignty: Ecuador's Strategic Silence on the Shrimp Ban, 2 BRIDGES BETWEEN TRADE AND SuSTAINABLE DEVELOPMENT, Apr.-May 1998, at 13.

84. Alan Oxley, Poor Environmental Policy: The Fundamental Problem in the "Trade and Environment" Debate, in THE NEXT TRADE NEGOTIATING ROUND: EXAMINING THE AGENDA FOR SEATTLE 63, 71 (Jagdish Bhagwati ed., 1999).

85. I.M. DEstler \& PETER J. Balint, THE NEW Politics of AMERICAN TRADE: TRADE, LABOR, AND THE ENVIRONMENT 35 (1999). 
One of the basic principles of the WTO is that member countries may not discriminate between "like products." This has hitherto normally been interpreted as preventing discrimination between goods on the basis of how they are produced. . . To allow discrimination on the basis of production and processing methods (PPMs), there would have to be a re-interpretation of the crucial term "like product." ${ }^{26}$ (House of Lords, Select Committee on European Communities, 2000.)

And, we noted, WTO law does not allow countries to discriminate against like products, whatever their different environmental impacts. This prohibition makes little environmental sense. The way a product is produced is one of the three central questions for an environmental manager. ${ }^{87}$ (U.N. Environmental Programme \& International Institute for Sustainable Development, 2000.)

The WTO agreed in the Uruguay Round that, although states can control the import of final products that are damaging to health and environment, they cannot restrict the import of goods on the grounds that they have been produced using harmful process and production methods (PPMs). ${ }^{88}$ (Bill Jordan, International Confederation for Free Trade Unions, 2001.)

WTO rules do not allow its members to discriminate between so-called "like products." This is widely interpreted as implying they cannot discriminate between goods on the basis of non-product related process and production methods (PPMs). ${ }^{89}$ (European Commission, 2001.)

Expressed in the "like product" norm, where products are seen to be equivalent, their origin-or their production processes and methods (PPMs) background-may not constitute any grounds for discriminating treatment through national policy. ${ }^{90}$ (Martin Weber, Southampton University, 2001.)

The position of most developing countries is that the TBT Agreement prohibits the use of standards based on non-product-related PPMs because its definition of standards does not include those that are based on such PPMs and product differentiation on these grounds is not allowed by GATT/WTO jurisprudence. ${ }^{91}$ (José Maria Figueres Olsen, et al., World Economic Forum, 2001.)

What is the authority for this widely-shared opinion? Certainly, the text of the GATT does not forbid national regulations, taxes, tariffs, or import bans based on the production process. On the contrary, the GATT allows governments to discriminate against imports made in prohibited ways. For example, governments can take customs action against an imported article made using a subsidy, or whose producer prices it too low, or whose producer

86. House OF LORDS Select COMMTTTEe ON EUROPEAN COMMUNTIES, THE WORLD TRADE ORGANISATION: THE EU MANDATE AFTER SEATTLE, June 13, 2000, fit 223-24.

87. U.N. ENVRONMENT PROGRAMME \& INTERNATIONAI INSTITUTE fOR SUSTAINABle DEVELOPMENT, ENVIRONMENT AND TRADE: A HANDBOOK 43 (2000).

88. Bill Jordan, Building a WTO That Can Contribute Effectively to Economic and Social Development Worldwide, in THE ROLE OF THE WORLD TRADE ORGaNZATION IN GLOBAL GOVERNANCE 243, 254 (Gary P. Sampson ed., 2001).

89. European Commission, Towards Sustainable Trade, Trade Policy Dialogue with Civil Society, Ad-Hoc Meeting on PPMs, 31 May 2001, Draft Agenda, available at http://europa.eu.int/comm/trade/csc/draftagd ppm.htm.

90. Martin Weber, Competing Political Visions: WTO Governance and Green Politics, 1 GLOB. ENVTL. POL. 92, 99 (2001) (internal citation omitted).

91. José Maria Figueres Olsen, José Manuel Salazar-Xirinachs, \& Mónica Araya, Trade and Environment at the World Trade Organization: The Need for a Constructive Dialogue, in THE ROLE OF THE WORLD TRADE ORGANIZATION IN GLOBAL GOVERNANCE, supra note 88, at 155, 174. The three authors, from Costa Rica, are reporting opinions expressed by others. 
does not have the requisite intellectual property licenses. ${ }^{92}$ The consumer may not agree with the governmental decision that these methods of production should be attacked with trade measures. The subsidized, low-cost imported fish will taste as good as the higher-cost domestic fish. Nevertheless, the GATT permits governments to impose PPMs of this sort despite the fact that the behavior being complained about has no effect on the product as such.

Even without explicit language, however, GATT rules may still prohibit environmental PPMs. As noted above, many commentators so contend. Over the years, the GATT Secretariat has taken both sides of the debate. When it first addressed the matter in 1971, the Secretariat explained:

\begin{abstract}
A shared resource, such as a lake or the atmosphere, which is being polluted by foreign producers may give rise to restrictions on trade in the product of that process justifiable on grounds of the public interest in the importing country of control over a process carried out in an adjacent or nearby country. ${ }^{93}$
\end{abstract}

Twenty years later, after environmental concerns grew in importance, the GATT Secretariat shifted its stance and asserted that "[i]n principle, it is not possible under GATT's rules to make access to one's own market dependent on the domestic environmental policies or practices of the exporting country." Then WTO Director-General Renato Ruggiero reaffirmed this negative view when he stated in a 1997 speech:

\footnotetext{
What a country cannot do under WTO rules, however, is apply trade restrictions to attempt to change the process and production methods - or other policies - of its trading partners. Why? Basically because the issue of production and process methods lies within the sovereign jurisdiction of each country.
}

Even today, the WTO Secretariat continues to insist that PPMs violate trade rules. The WTO website states:

The WTO agreements are interpreted to say two important things. First, trade restrictions cannot be imposed on a product purely because of the way it has been produced. Second, one country cannot reach out beyond its own territory to impose its standards on another country. ${ }^{96}$

92. GATT, supra note 3, arts. VI:3, VI:2, XX(d). Article VI:3 implicitly authorizes countervailing duties against imports produced with the help of government subsidies. Article VI:2 authorizes antidumping duties against dumped products. Article XX(d) implicitly authorizes trade measures to protect patents, trademarks, and copyrights.

93. GATT, INDUSTRIAL POLLUTION CONTROL AND INIERNATIONAL TRADE, GATT Studies in International Trade No. 1, July 1971 (emphasis added).

94. GATT Secretariat, supra note 51, at 23.

95. Renato Ruggiero, A Shared Responsibility: Global Policy Coherence for our Global Age, Address to the Conference on "Globalization as a Challenge for German Business: Export Opportunities for Small and Medium-sized Companies in the Environmental Field," (Dec. 9, 1997), available at http://www.wto.org/english/news_e/sprr_e/bonn_e.htm.

96. TRADING INTO THE FUTURE: TḦE INTRODUCTION TO THE WTO 47 (2d ed., 1999), available at http://www.wto.org/english/thewto_e/whatis_e/tif_e/tif_e.htm. In November 2001, the WTO Secretariat published an online "resource booklet" for the Fourth Ministerial Conference in Doha, Qatar. It states:

The WTO, like its predecessor the GATT, does not permit its Members to distinguish between products that have the same characteristics ("like" 
This Article cites the WTO Director-General and the WTO Secretariat not because they have any role in issuing formal interpretations of WTO law. They do not. Rather, the point being made is that the words of these international officials will tend to influence and inform public opinion, and insufficient care is being taken to make legally accurate pronouncements.

In the next section, this Article will attempt to prove the contention that the WTO does not prohibit PPMs and to show that the dogma quoted above is incorrect. The central WTO agreement at issue is the GATT, which addresses trade in goods. The GATT caselaw on PPMs is nuanced and does not point to a prohibition on the use of such environmental instruments. Unless otherwise noted, all of the panel decisions discussed below have been adopted by the governments. Some of these decisions-issued between 1952 and 1994were products of the GATT trading system. The rest of the decisions-issued between 1996 and 2001 - are products of the current WTO system. WTO panels commonly rely on earlier decisions, including decisions authored by GATT panels. ${ }^{97}$

\section{A. Structure of GATT Obligations}

The structure of GATT obligations is as follows: A PPM could violate GATT Article I (most-favored-nation), or GATT Article III (national treatment), or GATT Article XI (elimination of quantitative restrictions). ${ }^{98}$ If

products) based on the differences in the way they were produced. Why?

Because to do so would bring the rules into conflict with the very basis of the gains from trade: differences in comparative advantage.

THE WTO . . . WHY IT MATTERS: A GUIDE FOR OFFICIALS, LEGISLATORS, CIVIL SOCIETY AND ALI. THOSE INTERESTED IN INTERNATIONAL TRADE AND GLOBAL GOVERNANCE 33 (2001) available at http://www-heva.wto-ministerial.org/english/thewto_e/minist_e/min01_e/min01_e.htm.

97. The Appellate Body has stated that while not binding in subsequent disputes, adopted panel reports should be taken into account by panels where they are relevant to any dispute. Report of the Appellate Body on Japanese Taxes on Alcoholic Beverages, WT/DS8/AB/R, at 15-16 (Oct. 4, 1996) [hereinafter Appellate Body Japanese Alcoholic Beverages Report] available at http://www.wto.org.

98. GATT Article I (General Most-Favoured-Nation Treatment) provides in part:

With respect to customs duties and charges of any kind imposed on or in connection with importation or exportation or imposed on the international transfer of payments for imports or exports, and with respect to the method of levying such duties and charges, and with respect to all rules and formalities in connection with importation and exportation, and with respect to all matters referred to in paragraphs 2 and 4 of Article III, any advantage, favour, privilege or immunity granted by any contracting party to any product originating in or destined for any other country shall be accorded immediately and unconditionally to the like product originating in or destined for the territories of all other contracting parties.

GATT, supra note 3, art. 1, \| 1 .

GATT Article III (National Treatment on Internal Taxation and Regulation) provides in part: 1. The contracting parties recognize that internal taxes and other internal charges, and laws, regulations and requirements affecting the internal sale, offering for sale, purchase, transportation, distribution or use of products, and internal quantitative regulations requiring the mixture, processing or use of products in specified amounts or proportions, should not be applied to imported or domestic products so as to afford protection to domestic production. 2. The products of the territory of any contracting party imported into the territory of any other contracting party shall not be subject, directly or indirectly, to internal taxes or other internal charges of any kind in excess of those applied, directly or indirectly, to like domestic products.... 
so, it would be reviewed under the General Exceptions in Article XX when there is an applicable exception. ${ }^{99}$ GATT Article I requires parties to treat a product of another party no less favorably than the like product of any other party. GATT Article III requires treating imported products from a party no less favorably than like domestic products. GATT Article XI prohibits import and export bans and quotas (subject to certain exceptions not relevant here). GATT Article XX provides for General Exceptions to the entire Agreement.

The relationship between the GATT disciplines and Article XX is subject to different interpretations. One school of thought is that GATT Articles I, III, and XI impose disciplines on governments, and that GATT Article XX provides exceptions to those disciplines. Whether a national measure is in conformity with the GATT can only be determined by looking at both the disciplines and the exceptions in tandem. Viewed in this way, when a measure fails to provide national treatment, it should not be called a

4. The products of the territory of any contracting party imported into the territory of any other contracting party shall be accorded treatment no less favourable than that accorded to like products of national origin in respect of all laws, regulations and requirements affecting their internal sale, offering for sale, purchase, transportation, distribution or use.

....

5. No contracting party shall establish or maintain any internal quantitative regulation relating to the mixture, processing or use of products in specified amounts or proportions which requires, directly or indirectly, that any specified amount or proportion of any product which is the subject of the regulation must be supplied from domestic sources.... ....

7. No internal quantitative regulation relating to the mixture, processing or use of products in specified amounts or proportions shall be applied in such a manner as to Id. at art. 3. allocate any such amount or proportion among external sources of supply.

GATT Article XI (General Elimination of Quantitative Restrictions) provides in part: No prohibitions or restrictions other than duties, taxes or other charges, whether made effective through quotas, import or export licences or other measures, shall be instituted or maintained by any contracting party on the importation of any product of the territory of any other contracting party or on the exportation or sale for export of any product Id. at art. 11 . destined for the territory of any other contracting party.

99. GATT Article XX (General Exceptions) provides in part:

Subject to the requirement that such measures are not applied in a manner which would constitute a means of arbitrary or unjustifiable discrimination between countries where the same conditions prevail, or a disguised restriction on international trade, nothing in this Agreement shall be construed to prevent the adoption or enforcement by any contracting party of measures:

...

(b) necessary to protect human, animal or plant life or health....

(d) necessary to secure compliance with laws or regulations which are not inconsistent with the provisions of this Agreement, including those relating to customs enforcement, the enforcement of monopolies operated under paragraph 4 of Article II and Article XVII, the protection of patents, trade marks and copyrights, and the prevention of deceptive practices;

(e) relating to the products of prison labour,

...

(g) relating to the conservation of exhaustible natural resources if such measures are made effective in conjunction with restrictions on domestic production or consumption; 
GATT violation merely because it violates Article III; a determination of GATT status requires a review of Article XX too.

The opposing school of thought is that GATT Articles I, III, and XI grant (or delineate) "rights" of a WTO member country to have the exports of its private actors accepted by other WTO member countries. Viewed in this way, the Article I, III or XI rights of the exporting country will need to be weighed against the Article XX rights of the importing country to rely upon one of the listed exceptions. Acting inconsistently with Article I constitutes a GATT violation, but it might be excusable by Article XX.

The WTO Appellate Body aligns itself with the second school. In the U.S. Gasoline case, the Appellate Body held that "if those [Article XX] exceptions are not to be abused or misused, in other words, the measures falling within the particular exceptions must be applied reasonably, with due regard both to the legal duties of the parties claiming the exception and the legal rights of the other parties concerned." ${ }^{100}$ In the U.S. Shrimp-Turtle case, the Appellate Body stated that

\begin{abstract}
WTO Members need to maintain a balance of rights and obligations between the right of a Member to invoke one or another of the exceptions in Article XX, specified in paragraphs (a) to (j), on the one hand, and the substantive rights of the other Members under the GATT 1994, on the other hand. Exercise by one Member of this right to invoke an exception, such as Article XX(g), if abused or misused, will, to that extent, erode or render naught the substantive treaty rights in, for example, Article XI:l, of other Members. $^{101}$
\end{abstract}

The Appellate Body did not explain why Article XI:1 provides a "substantive" right, while Article XX does not. More fundamentally, the Appellate Body does not explain how Article XI:1 confers a "right" on any exporting government. Its exporter-oriented perspective can also be seen in the Japan Alcoholic Beverages case where the Appellate Body alludes to the "sheltering scope" of Article III. ${ }^{102}$ This language seems to suggest that Article III shields measures from GATT review by conferring a right to undertake them.

By using the language of rights in this way, the Appellate Body weakens the General Exceptions of Article XX. ${ }^{103}$ If the exporting country has a WTO "right" to have its exports accepted, then there will be a tendency to interpret

100. Report of the Appellate Body Concerning United States Standards for Reformulated and Conventional Gasoline, WT/DS2/AB/R, at 21-22 (Apr. 29, 1996) available at http://www.wto.org [hereinafter Appellate Body Gasoline Report].

101. Appellate Body Shrimp-Turtle Report, supra note 15, ๆ 156 (emphasis added). See also id. I 159 (discussing the "competing rights" under Articles XI and XX); id. II 181-82 (suggesting that the U.S. import ban results in a suspension of the treaty rights of other WTO Members).

102. The Appellate Body says: "The broad purpose of Article III of avoiding protectionism must be remembered when considering the relationship between Article III and other provisions of the WTO Agreement. . . . The sheltering scope of Article III is not limited to products that are the subject of tariff concessions under Article II." Appellate Body Japanese Alcoholic Beverages Report, supra note 97 , at 17 .

103. To be sure, the DSU employs the term "rights." For example, Article 3.2 states: "The dispute settlement system of the WTO is a central element in providing security and predictability to the multilateral trading system. The Members recognize that it serves to preserve the rights and obligations of Members under the covered agreements. ..."DSU, supra note 75, art. 3.2 . 
Article XX narrowly and begrudgingly so as not to interfere with that putative right. In characterizing Article XI as "substantive," while implying that Article XX is not, the Appellate Body positions the two provisions at different levels. The Appellate Body thus makes it easier for panels to ignore the overriding injunction of Article XX, which provides that, subject to certain requirements, "nothing" in the GATT shall be construed to prevent the adoption or enforcement of listed measures.

A recent decision by a WTO arbitral panel, in the Brazil Aircraft case, illustrates the tendency to minimize Article XX. ${ }^{104}$ In that case, the panel had to interpret item $(\mathrm{k})$ of Annex I to the Agreement on Subsidies and Countervailing Measures (SCM). Item (k) contains a rule and an exception. ${ }^{105}$ Looking at item (k), the panel said that "[a] possible justification under item (k), like a justification under Article XX of the GATT 1994, does not change the legal nature of the measure." ${ }^{106}$ While this may be a good analysis for the SCM Agreement, it would be a troublesome analysis for the GATT because a justification of a measure under Article XX does change its legal status. An environmental measure that is inconsistent with GATT Article III, and might therefore violate the GATT, is nevertheless GATT-compliant if it can be justified under Article XX. Therefore, Article XX does change the "legal nature of the measure" in the sense that it lays out a test for environmentally justified measures that the panel is legally bound to apply. Unfortunately, under current WTO jurisprudence, the implication of Article XX must be characterized less generously.

This issue of orientation is noted at the start because it may facilitate the understanding of PPM jurisprudence presented below. The first section will

104. Decision by the Arbitrators Concerning Recourse to Arbitration by Brazil under Article 22.6 of the DSU and Article 4.11 of the SCM Agreement, WT/DS46/ARB (Aug. 28, 2000), available at http:// www.wto.org [hereinafter Brazil Aircraft Article 22 Arbitration Report]. The arbitrator's decision is to be accepted by the parties as final. DSU, supra note 75, art. 22.7. The purpose of this arbitration was to review Canada's proposed level of countermeasures against Brazil. Canada was entitled to take countermeasures in response to Brazil's non-compliance with WTO rules in the Aircraft dispute. The arbitrators authorized $\$ 344$ million (Canadian) which Canada has not yet imposed.

105. Item (k), in the illustrative list of export subsidies, states that:

The grant by governments (or special institutions controlled by and/or acting under the authority of governments) of export credits at rates below those which they actually have to pay for the funds so employed (or would have to pay if they borrowed on international capital markets in order to obtain funds of the same maturity and other credit terms and denominated in the same currency as the export credit), or the payment by them of all or part of the costs incurred by exporters or financial institutions in obtaining credits, in so far as they are used to secure a material advantage in the field of export credit terms.

Provided, however, that if a Member is a party to an international undertaking on official export credits to which at least twelve original Members to this Agreement are parties as of 1 January 1979 (or a successor undertaking which has been adopted by those original Members), or if in practice a Member applies the interest rates provisions of the relevant undertaking, an export credit practice which is in conformity with those provisions shall not be considered an export subsidy prohibited by this Agreement.

Agreement on Subsidies and Countervailing Measures, Apr. 15, 1994, WTO Agreement, Annex 1A, Annex I (of SCM Agreement), Item (k), LEGAL TEXTs, supra note 3, at 267.

106. Brazil Aircraft Article 22 Arbitration Report, supra note 104, [3.39. Article XX was not an issue in this case so this analogy is dicta. 
consider GATT Article I, the next section Article III, and the last section Article XX. The Article XI caselaw has not explicitly addressed PPMs because a PPM-based import ban would clearly violate Article XI.

As a reference point in examining the cases to be discussed below, Table I lists the PPM cases and the type of PPM used.

\begin{tabular}{|l|l|}
\hline \multicolumn{2}{|c|}{ Table I } \\
\hline \multicolumn{2}{|c|}{ Category of PPM Used in GATT/WTO Cases } \\
\hline How-Produced & Automotive Spring Assemblies \\
\hline Producer Characteristics & $\begin{array}{l}\text { Indonesia Automobile } \\
\text { Canada Automotive } \\
\text { U.S. Alcoholic Beverages } \\
\text { U.S. Automotive Taxes } \\
\text { U.S. Gasoline }\end{array}$ \\
\hline Government Policy & $\begin{array}{l}\text { Belgian Family Allowances } \\
\text { Tuna-Dolphin I } \\
\text { Tuna-Dolphin II } \\
\text { Shrimp-Turtle }\end{array}$ \\
\hline
\end{tabular}

\section{B. GATT Article I-Most Favored Nation (MFN) Rule}

GATT Article I:1 (General Most-Favored-Nation Treatment) provides that with respect to customs duties, taxes, regulations, and import rules, any advantage or favor granted by a Party to any product shall be accorded immediately and unconditionally to the "like" product of all other Parties. ${ }^{107}$ This provision means that a WTO Member government cannot discriminate by treating the product of one WTO Member country better than the like product of another member country. The decision as to whether two products are "like" will often determine the outcome of a case because Article I does not prohibit differential treatment of unlike products.

One of the earliest GATT decisions, "Belgian Family Allowances," considered whether a PPM violated Article I. ${ }^{108}$ At issue was a Belgian tax on imports purchased by local government bodies. ${ }^{109}$ The six-percent tax was devoted to the family allowance program in Belgium that was otherwise funded by employer taxes. ${ }^{110}$ Not every country, however, was subject to the

107. For exact text, see supra note 98.

108. Belgian Family Allowances, GATT B.I.S.D. (1st Supp.) at 59-62 (1953).

109. Id. I 1 .

110. Robert E. Hudec, The GATT Legal System: A Diplomat's Jurisprudence, in ESSAYS ON THE NATURE OF INTERNATIONAL TRADE LAW 17, 42 (Robert E. Hudec ed., 1999). 
import tax. An exemption was available for countries that imposed an employer tax for family allowances similar to Belgium's tax. ${ }^{11}$ The two plaintiff governments, Denmark and Norway, complained that the tax violated Article I because an exemption had been given to Sweden but not to them, even though they had similar family allowance programs. ${ }^{12}$ The panel sided with the plaintiffs, but on broader grounds. The panel reasoned that since Belgium had granted the exemption to some GATT parties, Article I required Belgium to grant the exemption to every other GATT party regardless of whether a government qualified for the exemption by having a similar family allowance program. ${ }^{113}$

The panel found that Belgium was levying a non-product-related PPM tax on other countries based on a (foreign) government policy standard. In the panel's view, the nature of an exporting country's family allowance program was "irrelevant" to GATT Article I, which does not permit discrimination dependent on conditions. ${ }^{14}$ Because Belgium did not claim an Article XX exception, the case ended with the finding of an Article I violation.

No other Article I cases involving a non-product-related PPM ensued before the advent of the WTO. In a 1981 decision, a panel considered a product-related PPM and found that the distinction was not enough to prevent two similar products from being deemed "like." distinctive methods of cultivation and processing of coffee beans justified different tariffs for various types of unroasted coffee. ${ }^{116}$

The WTO has considered two GATT Article I disputes involving PPMs, both concerning automobiles. In the Indonesia Automobile case, Japan, the European Communities, and the United States complained that Indonesia applied higher customs duties and sales taxes to imported products when the exporting manufacturer did not utilize a sufficient amount of Indonesian parts or labor. ${ }^{117}$ In the Canada Automotive case, Japan and the European Communities complained that Canada provided an import duty exemption for an eligible corporation conditioned on its having a manufacturing presence and sufficient value-added in Canada. ${ }^{118}$ In both cases, the panels found a violation of GATT Article I. In neither case did the defendant invoke an Article XX exception.

111. Id. at 43 .

112. Id. at $44-45$

113. Belgian Family Allowances, supra note 108, $\$ 173$. 6 .

114. Id. ๆ 3.

115. Spain - Tariff Treatment of Unroasted Coffee, June 11, 1981, GATT B.I.S.D. (28th Supp.) at 102, 112, 14.10 (1982). The panel held that Spain's higher tariffs on "unwashed Arabica" and Robusta coffee violated GATT Article I because such coffee was a like product to the mild coffee that could be imported duty free.

116. Id. ๆ 4.6 .

117. WTO Dispute Panel Report on Indonesia - Certain Measures Affecting the Automobile Industry, WT/DS54/R (July 2, 1998), available at http://www.wto.org [hereinafter Indonesia Automobile Panel Report]. This decision was not appealed.

118. WTO Dispute Panel Report on Canada - Certain Measures Affecting the Automotive Industry, WT/DS/139/R I 10.4 (Feb. 11, 2000), available at http://www.wto.org [hereinafter Canada Automotive Report]. 
In the Indonesia Automobile decision, the panel held that according to GATT Article I, an advantage "cannot be made conditional on any criteria that is not related to the imported product itself."119 Elaborating on this point, the panel stated that "[i]n the GATT/WTO, the right of Members cannot be made dependent upon, conditional on or even affected by, any private contractual obligations in place." 220 The panel concluded that Indonesia was levying a PPM tax and tariff based on producer characteristics and domestic content, and deemed that to be an Article I violation.

In the Canada Automotive decision, the panel held that GATT Article I was being violated, but adopted a more nuanced interpretation of the Article I discipline. Specifically, the panel said, "We therefore do not believe that ... Article I: 1 must be interpreted to mean that making an advantage conditional on criteria not related to the imported product itself is per se inconsistent with Article I:1, irrespective of whether and how such criteria relate to the origin of the imported products." 212 In other words, the panel suggested that truly originneutral criteria might be permissible under Article I. The panel was careful to distinguish the holdings in the Belgian Family Allowances and Indonesia Automobile cases, both of which it viewed as relating to origin-based discrimination..$^{122}$ In the instant case, the panel concluded that the criteria were not origin-neutral, and so Article I was being violated. ${ }^{123}$ On appeal, the Appellate Body upheld the panel's finding of the Article I:1 violation but did not address the panel's interpretive point. ${ }^{24}$

The Article I caselaw reviewed above can be summarized as follows: A government policy standard violates MFN because it is origin-contingent. A producer characteristics standard was held to be a violation in the Indonesia and Canada automobile cases, but the latter panel suggested that PPMs are not per se violations of MFN. As this discussion shows, the law of PPMs under Article I is somewhat unsettled. It is also worth noting that no how-produced standard has been reviewed under Article I.

\section{GATT Article III-National Treatment Rule}

GATT Article III (National Treatment) contains disciplines on domestic taxation and regulation. ${ }^{125}$ Under Article III:2, imported products shall not be subject to taxes of any kind in excess of those applied to like domestic products. Under Article III:4, imported products shall be accorded treatment no less favorable than that accorded to like products of national origin.

119. Indonesia Automobile Panel Report, supra note 117, ๆ 14.143.

120. Id. \14.145.

121. Canada Automotive Report, supra note 118, I 10.24. See also id. If 10.29-30 (elaborating on this point).

122. Id. If $10.26,10.28$.

123. Id. ๆ 10.50

124. WTO Appellate Body Report on Canada - Certain Measures Affecting the Automotive Industry, WT/DS/139/AB/R, II 78, 81 (May 31, 2000), available at http://www.wto.org.

125. For exact text, see supra note 98 . 
The drafters of Article III recognized that governments sometimes utilize processing regulations, and Article III does not prohibit that practice. Article III: 1 provides that internal taxes and regulations affecting the internal sale, transportation, distribution or use of products, "and internal quantitative regulations requiring the mixture, processing or use of products in specified amounts or proportions, should not be applied to imported or domestic products so as to afford protection to domestic production."126 In stating that such regulations should not afford protection to domestic production, Article III: 1 implies that mixture or processing regulations that do not afford protection to domestic production are not prohibited. The same rule can be inferred from other provisions in Article III that address mixture and processing. For example, Article III:5 prohibits mixture/processing regulations linked to domestic content. $^{127}$ Article III:7 prohibits mixture/processing regulations that seek to allocate proportions among external sources of supply. ${ }^{128}$ If all mixture/processing regulations were prohibited, then Article III presumably would not have three prohibitions aimed at particular kinds of mixture/processing regulations.

Suppose that a government had a regulation prohibiting the sale of a wood product unless at least eighty percent of its weight came from sustainably harvested timber of any national origin. That how-produced PPM would specify a minimum proportion for processing. Written this way, such a measure would not seem to be a per se violation of Article III.

Nevertheless, as shown below, adjudicatory panels considering Article III have objected to PPMs in the few cases where such measures were reviewed. During the GATT era (1947-94), there were four cases, all against the United States. Since the advent of the WTO, two cases have arisen, but other decisions may bear on how Article III would be applied to PPMs.

The earliest GATT case, decided in 1991, is known as the Tuna-Dolphin I Report. ${ }^{129}$ At that time, the United States imposed a "primary" import ban on tuna from countries that did not have a regulatory regime to protect dolphins comparable to the U.S. regime. ${ }^{130}$ Mexico, one of the embargoed countries, complained that this law violated Article III. ${ }^{131}$ The U.S. import ban was a government policy standard aimed at foreign laws. ${ }^{132}$ Indeed, the law also contained a fishery-practice standard by requiring Mexico to keep its overall dolphin killing rate no more than 25 percent higher than the United States'

126. For exact text, see supra note 98.

127. For exact text, see supra note 98.

128. For exact text, see supra note 98.

129. United States-Restrictions on Imports of Tuna, Sept. 3, 1991, GATT, B.I.S.D. (39th Supp.) at 155 (1991) (not adopted) [hereinafter Tuna Dolphin I Report]; see Henry L. Thaggert, $A$ Closer Look at the Tuna-Dolphin Case: "Like Products" and "Extrajurisdictionality" in the Trade and Environment Context, in 1 TRADE AND THE ENVIRONMENT: THE SEARCH FOR BALANCE 69-95 (James Cameron et al. eds., 1994).

130. Marine Mammal Protection Act Amendments of 1988, Pub. L. No. 100-711, §4. The current law contains a different prohibition.

131. Tuna Dolphin I Report, supra note 129, I 3.16.

132. Id. . III 2.5-6. 
annual rate. ${ }^{133}$ The panel ruled that Article III "covers only those measures that are applied to the product as such." Therefore, the U.S. measure regarding dolphins did not fit within the confines of Article $\mathrm{II}$ because this PPM "could not possibly affect tuna as a product." ${ }^{34}$ The panel went on to say that if the U.S. measure were covered by Article III, such a measure would constitute a violation because the United States treatment of Mexico cannot be predicated on whether or not the incidental taking of dolphins by Mexican vessels corresponds to that of U.S.-flag vessels. ${ }^{135}$ When the matter was debated before the Council in 1992, the European Commission called for the adoption of the Tuna-Dolphin report as "a necessary first step in clarifying the relationship between environmental policies and GATT provisions." ${ }^{136}$ Nevertheless, this judgment was not adopted by the GATT Council and today carries no legal weight in the WTO. ${ }^{137}$

The U.S. Alcoholic Beverages decision came a few months later. ${ }^{138}$ This dispute involved numerous causes of action by Canada, only one of which is discussed here. Canada complained about an excise tax credit in the State of Minnesota for small beer breweries, regardless of whether they were domestic or foreign. ${ }^{139}$ Canada argued that this tax measure discriminated against its large breweries. The panel held that beer from micro-breweries is a like product to beer from large breweries, and so a tax that distinguishes the two violates Article III:2. ${ }^{140}$ This tax credit is an example of a producer characteristics PPM.

The second Tuna-Dolphin decision came in 1994 and it too was not adopted. ${ }^{141}$ The plaintiffs were the European Communities and the Netherlands acting for the Netherlands Antilles. This panel's Article III holding was

133. Id. The U.S. import ban on tuna is not a producer characteristics standard because no solitary producer can meet it on its own. It is also not a how-produced standard since the import ban is country-wide. Implicitly, then, the import ban calls on each foreign country to impose a government policy standard.

134. Id., I 5.14. In a recent commentary, Robert Hudec states that the panel's suggestion that Article III does not cover process-based regulations "is just plain wrong." Robert E. Hudec, The Product-Process Doctrine in GATT/WTO Jurisprudence, in NEW DIRECTIONS IN INTERNATIONAL ECONOMIC LAW 187, 198 (Marco Bronckers \& Reinhard Quick eds., 2000).

135. Tuna Dolphin I Report, supra note 129, I 5.15. The panel's overall ruling was that the United States was imposing a quantitative restriction in violation of GATT Article XI and that therefore the U.S. trade ban violated GATT rules.

136. GATT Council, Minutes of Meeting held on 18-20 February 1992, GATT Doc. C/M/254, March 10, 1992, at 23.

137. The Appellate Body has stated that unadopted GATT or WTO panel reports have no legal status in the WTO Appellate Body Japanese Alcoholic Beverages Report, supra note 97, at 15.

138. United States-Measures Affecting Alcoholic and Malt Beverages, March 19, 1992, GATT B.I.S.D. (39th Supp.) at 206 (1992) [hereinafter U.S. Alcoholic Beverages Report].

139. Id. I 5.19. For purposes of its decision, the panel assumed that the Minnesota tax credit was available to Canadian producers.

140. Id. From the report of the case, the U.S. Trade Representative seems to have made little effort to defend Minnesota's law and to provide a non-protectionist rationale for it.

141. United States-Restrictions on Imports of Tuna, June 16, 1994, 33 I.L.M. 839 (1994) (not adopted) [hereinafter Tuna-Dolphin II Report]. The facts and complaints in the two Tuna-Dolphin cases were the same, although the second case focused more on the intermediary embargo. Under the intermediary embargo provisions, the U.S. government was banning tuna imports from countries that had not stopped buying tuna from countries subject to the U.S. primary embargo. Id. I 2.15. 
similar to that of the first Tuna-Dolphin panel. The second panel contended that Article III did not apply to laws "related to policies or practices that could not affect the product as such." ${ }^{142}$

The last pre-WTO decision was U.S. Automobile Taxes, and it too was not adopted. ${ }^{143}$ The European Communities lodged several complaints, one of which was that the U.S. Corporate Average Fuel Economy (CAFE) regulation violated Article III:4 because it was based on a fleet averaging method that treated domestic and foreign-made autos separately. ${ }^{144}$ The panel issued a broad ruling that "Article III:4 does not permit treatment of an imported product less favourable than that accorded to a like domestic product, based on factors not directly relating to the product as such." ${ }^{145}$ Thus, fleet averaging violated Article III because this method was "based on the ownership or control relationship of the car manufacturer" and therefore "did not relate to cars as products." "146 This was a producer characteristics PPM. The panel found that this Article III violation did not qualify for GATT's environmental exception, and it therefore held that the CAFE law violated the GATT. ${ }^{147}$

The first WTO panel decision-the U.S. Gasoline case-involved a producer characteristics PPM regulation for gasoline composition. ${ }^{148}$ Venezuela and Brazil complained that the U.S. regulation, which required reduction from a pollution baseline, was discriminatory because it assigned foreign producers a standard baseline while giving domestic refiners an individual baseline. ${ }^{149}$ The regulation was not based on the chemical composition of a particular shipment of gasoline, but rather on the entire output of a domestic refinery or entire output of a foreign refinery that was to be exported to the United States. The complaining governments argued that because foreign gasoline was generally higher-polluting, the assignment of a standard baseline required some of those producers to undertake greater reductions in polluting ingredients than if they had been given an individual baseline. ${ }^{150}$

The U.S. regulation was undoubtedly a violation of the national treatment rule. Yet in so holding, the U.S. Gasoline panel went farther, issuing a broad decision that built on the U.S. Alcoholic Beverages and Automobile Taxes decisions. Noting that the U.S. regulation had been defended on the ground that data from foreign producers was unverifiable, the panel held that

142. Tuna-Dolphin II Report, supra note 141, ๆ 5.8 .

143. GATT Dispute Settlement Panel Report on United States Taxes on Automobiles, 33 I.L.M. 1397-1461 (October 11, 1994) (not adopted) [hereinafter U.S. Automobile Taxes Report].

144. Id. $\$ 3.272$. In fleet averaging, the U.S. government sets fuel economy standards based on the average achieved by a foreign manufacturer for all its autos shipped to the United States. Id. II 2.1415.

145. Id. \ 5.54.

146. Id. $\Upsilon 5.55$.

147. Id. $\llbracket 6.1(\mathrm{c})$.

148. WTO Dispute Panel Report on United States-Standards for Reformulated and Conventional Gasoline, Report of the Panel, WT/DS2/R (Jan. 29, 1996), available at http://www.wto.org [hereinafter U.S. Gasoline Panel Report].

149. Id. โโ $3.12,6.3$.

150. Id. \6.10. 
Article III:4 "does not allow less favorable treatment dependent on the characteristics of the producer and the nature of the data held by it."151 More generally, the panel suggested that the identification of like products in Article III:4 needs to be done "on the objective basis of their likeness as products" and not according to "extraneous factors" like those in the U.S. Gasoline dispute. ${ }^{152}$ This Article III:4 holding was not appealed and was the backbone of the WTO decision that the U.S. measure violated the GATT.

The second WTO case was Indonesia Automobile. The panel found an Article III: 2 violation because the tax measures were based on nationality and origin, and "other factors not related to the product itself."153 This was similar to the panel's ruling on Article I. ${ }^{154}$

The third case, Japan Alcoholic Beverages, did not consider a PPM, but in rejecting the so-called "aim-and-effect" test, its holding makes it more likely that PPMs will be found to violate GATT Article III. ${ }^{155}$ Aim-and-effect was a treaty interpretation developed in GATT caselaw and commentary during the $1990 \mathrm{~s}$, which sought to define product likeness more narrowly so as to prevent Article III from unnecessarily infringing on national regulatory autonomy. ${ }^{156}$ As the U.S. Alcoholic Beverages panel explained in 1992, "once products are designated as like products, a regulatory product differentiation, e.g., for standardization or environmental purposes, becomes inconsistent with Article III even if the regulation is not "applied ... so as [to] afford protection to domestic production."'157 In other words, if two products I and D are deemed "like" products, then taxing or regulating them differently, even when based on an objective environmental distinction, could be found to violate Article III if I is taxed more or treated less favorably than D. To avoid such a holding, the proponents of the "aim-and-effect" test sought to have panels consider whether the disputed tax or regulation had a protective aim or effect,

151. Id. \6.11.

152. Id. 76.12 .

153. Indonesia Automobile Panel Report, supra note 117, ffl 14.112-113.

154. See text accompanying supra note 119.

155. See WTO Dispute Panel Report on Japan-Taxes on Alcoholic Beverages, WT/DS8/R \{ff 6.17-18 (July 11, 1996), available at http://www.wto.org [hereinafter Japan Alcoholic Beverages Panel Report]. The plaintiffs were the United States, the European Community, and Canada. These governments complained that Japan imposed higher excise taxes on imported liquors, such as vodka and whisky, than on the domestically produced liquor Shochu. The case centered on whether these were like products, directly competitive or substitutable products, or neither of these. The panel found that vodka was a like product and that other imports were directly competitive or substitutable to domestic Shochu. Because Shochu was taxed less, the panel held that GATT Article III was being violated. The Appellate Body upheld the panel's reasoning with minor modifications.

156. Robert E. Hudec, GATT/WTO Constraints on National Regulation: Requiem for an "Aims and Effects" Test, 32 INT'L L. 619 (1998). One intellectual foundation of this test is discussed in Frieder Roessler, The Constitutional Function of the Multilateral Trade Order, in ESSAYS ON THE LEGAL STRUCTURE, FUNCTIONS, \& LIMTSS OF THE WORLD TRADE ORDER 109, 127-30 (2000). See also Rambod Behboodi, Legal Reasoning and the International Law of Trade-The First Steps of the Appellate Body of the WTO, J. WORLD TRADE 55, 87-88 (Aug. 1998) (supporting the decision by the Appellate Body to clear up the "mess" and dismiss the aim-and-effect test); Aaditya Mattoo \& Arvind Subramanian, Regulatory Autonomy and Multilateral Disciplines: The Dilemma and a Possible Solution, 1 J. INT'L ECON. L. 303 (1998) (contrasting the textual and contextual approach to ascertaining like products).

157. U.S. Alcoholic Beverages Report, supra note 138, ๆ 5.72. 
and, if it did not, then products I and D, treated differently based on the tax or regulation, could perhaps avoid characterization as like products.

The first time this test was invoked in a WTO proceeding, in the Japan Alcoholic Beverages dispute, the panel rejected such a test in an Article III:2 case. ${ }^{158}$ The Appellate Body upheld the panel and, in a later decision, the European Communities (EC) Bananas case, the Appellate Body stated its rejection of "aim-and-effect" explicitly with respect to GATT Article III:1. ${ }^{159}$

Although it was not propounded as a way to defend PPMs, the aim-andeffect test could have provided a doctrinal basis for distinguishing two otherwise like products that differ only in conformity to the PPM. Without the aim-and-effect test, a PPM-compliant domestic product may be easily deemed a "like" product to a PPM-non-compliant imported product. If so, an Article III violation will occur when government action denies the imported product an equal opportunity to compete in the domestic market.

The most recent Article III panel decision came in the European Communities Asbestos case. ${ }^{160}$ In response to a complaint by Canada, the panel found that a French import ban on asbestos violated Article III:4 because Canadian asbestos fiber was a "like" product to European substitute fiber that was permitted. ${ }^{161}$ The panel held that the risk to human health or life from the product could not be a factor in determining whether two products were "like" under Article III because that would allow a government "to avoid the obligations in Article XX."162 This was not a PPM decision since the French ban was based on the dangers of the product to the user; but if the decision had been upheld, it would have had negative implications for PPMs.

The Appellate Body reversed on this point, stating that "the health risks associated with a product may be pertinent in an examination of likeness

158. Japan Alcoholic Beverages Panel Report, supra note 155, โf 6.17, 6.23. One stated reason for rejecting the aim-and-effect test was that if protection of health could be accomplished without violating Article III, that could "circumvent" Article XX, which requires governments to show that a health measure is necessary. $I d$. $\{6.17$. The panel did not explain why a non-violation of Article III circumvents Article XX. In its interpretation of GATT Article XX(g) in the U.S. Gasoline case, the Appellate Body declared that this exception (relating to the conservation of exhaustible natural resources) "may not be read so expansively as seriously to subvert the purpose and object of Article III:4." Appellate Body Gasoline Report, supra note 100, at 17. The Appellate Body did not explain why Article III should delimit Article XX.

159. Appellate Body Japanese Alcoholic Beverages Report, supra note 97; WTO Appellate Body Report on European Communities-Regime for the Importation, Sale and Distribution of Bananas, WT/DS27/AB/R, I 241 (Sept. 9, 1997), available at http://www.wto.org (making clear that the Appellate Body had rejected this test). But see Howse \& Regan, supra note 44, at 266 (suggesting that the Appellate Body reject a test, but not reject wholesale the consideration of aims and effects in determining likeness of products).

160. WTO Dispute Panel Report on European Communities - Measures Affecting Asbestos and Asbestos Containing Products, WT/DS135/R (Sept. 18, 2000), available at http://www.wto.org [hereinafter EC Asbestos Panel Report]. The panel held that the French import ban did not violate the GATT because it qualified for the Article XX(b) exception. The Appellate Body affirmed the panel's judgment and overturned the panel's ruling on Article III.

161. Id. . $8.144,8.150,8.157,8.158$.

162. Id. $\ 8.130$. Canada argued that "[t]he toxicity of a product is not recognized as a criterion for the evaluation of likeness." Id. $\llbracket 8.118$. 
under Article III:4 of the GATT 1994."'163 The Appellate Body said that it disagreed with the panel's suggestion that recourse to Article III could nullify Article XX. ${ }^{164}$ On the contrary, according to the Appellate Body, "Article III:4 and Article XX(b) are distinct and independent provisions of the GATT 1994 each to be interpreted on its own."165 The Appellate Body went on to say that the fact that an interpretation of Article III:4 "implies a less frequent recourse to Article $\mathrm{XX}(\mathrm{b})$ does not deprive the exception in Article XX(b) of effet utile."166

The Appellate Body's decision articulates the proper application of Article III. The Appellate Body points out that even when two products are deemed "like," there is no violation of Article III:4 unless the imported product is accorded "less favourable treatment."167 In other words, a regulator "may draw distinctions between products which have been found to be 'like,' without, for this reason alone, according to the group of 'like' imported products 'less favourable treatment' than that accorded to the group of 'like' domestic products." 168 The pivotal point will be whether there is "protection" of domestic products in the marketplace. ${ }^{169}$ The Appellate Body also makes clear that a determination of product "likeness" goes beyond the physical characteristics of the product. ${ }^{170}$ How this ruling affects PPMs remains to be seen.

In summary, the textual ambiguities in Article III have been resolved unfavorably to PPMs. A producer characteristics standard was held to be a violation of Article III in the U.S. Alcoholic Beverages, U.S. Gasoline, and Indonesia Automobile decisions. No how-produced standard has been tested, but WTO jurisprudence points to the likelihood that such a standard would be deemed a national treatment violation.

A competing view is presented by Robert Howse and Donald Regan, who contend that the text of Article III provides no support for the product/process distinction or the proposition that Article III prohibits all

163. WTO Appellate Body Report on European Communities-Measures Affecting Asbestos and Asbestos-Containing Products, WT/DS135/AB/R, I 113 (Mar. 12, 2001), available at http://www.wto.org [hereinafter Appellate Body Asbestos Report]; see also id. ๆ 192(b) (reversing the panel finding that a consideration of the health effects of the product was inappropriate). On the larger dimensions of the case, the Appellate Body upheld the panel's decision that France's import ban did not violate GATT rules. Id. I 193. For a discussion of the Appellate Body report, see Sydney M. Cone III, The "Asbestos" Case and Dispute Settlement in the World Trade Organization: The Uneasy Relationship Between Panels and the Appellate Body. 23 MiCH J. INT"L L. 2 (forthcoming 2002).

164. Appellate Body Asbestos Report, supra note 163, ๆ 115.

165. Id.

166. Id. "Effet utile" means useful effect. In making this point, the Appellate Body seems to be retreating from its holding in the U.S. Gasoline case that Article XX "may not be read so expansively as seriously to subvert the purpose and object of Article III:4." Appellate Body Gasoline Report, supra note 100 , at 17 .

167. Appellate Body Asbestos Report, supra note 163, ๆ 100.

168. Id.

169. Id.

170. Id. II 101-02 (including such criteria as the end-uses of product, consumers' tastes and habits in respect of the product, and the tariff classification of the products); see also id. If 113 (suggesting that the panel evaluate all of the relevant evidence). 
process measures. ${ }^{171}$ The authors contrast origin-neutral process measures (which would include how-produced standards as defined here) with countrybased measures (which would include government policy standards as defined here) and argue that while Article III prohibits country-based measures, it does not prohibit origin-neutral measures that distinguish products according to their production process. ${ }^{172}$ In their view, WTO panels remain free to enforce Article III to consider the aim and effect of a regulatory PPM in order to determine the legality of differential treatment of PPM-compliant and noncompliant products. ${ }^{173}$ This Howse and Regan study is flagged here because it provides a comprehensive analysis of Article III caselaw. Whatever the validity of their legal analysis, any optimism that future WTO panels will tolerate origin-neutral PPMs in the context of Article III would be unfounded.

\section{GATT Article XX-General Exceptions}

GATT Article XX lists ten exceptions to GATT disciplines. ${ }^{174}$ These exceptions are "[s]ubject to the requirement that such measures are not applied in a manner which would constitute a means of arbitrary or unjustifiable discrimination between countries where the same conditions prevail, or a disguised restriction on international trade." This requirement is now known as the "chapeau" of Article XX. Two of the exceptions would be available for environmental measures - paragraph (b) for measures "necessary to protect human, animal or plant life or health," and paragraph (g) for measures "relating to the conservation of exhaustible natural resources if such measures are made effective in conjunction with restrictions on domestic production or consumption." ${ }^{175}$ Article XX will be central to an analysis of PPMs because, as discussed above, many PPMs will violate Articles I, III, or $\mathrm{XI}$.

The first Article XX case on PPMs was U.S. Automotive Spring Assemblies in 1983. ${ }^{176}$ In this case, Canada complained about an import exclusion order against certain automotive spring assemblies produced in violation of a valid U.S. patent and without a license from the patent holder. ${ }^{177}$ This was a non-product-related how-produced standard. The panel ruled that

171. Howse \& Regan, supra note 44, at 252.

172. Id. at 253-72; Marco Bronckers \& Natalie McNelis, Rethinking the "Like Product" Definition in GATT 1994: Anti-Dumping and Environmental Protection, in REGULATORY BARRIERS AND THE PRINCIPLE OF NON-DiscrimINATION IN WORLD TRADE LAW, supra note 38 , at $345,376-77$ (suggesting, in a paper predating some recent WTO jurisprudence, that where based on broadly shared consumer preferences, PPM distinctions might not violate Article III); Naomi Roht-Arriaza, Precaution, Participation, and the "Greening" of International Trade Law, 7 J. ENVTL. L. \& LITIG. 57, 75 (1992) (making similar point to that of Howse \& Regan in 1992).

173. Howse \& Regan, supra note 44, at 264-68.

174. GATT, supra note 3 , art. XX.

175. Id. art. XX. For a discussion of the negotiation background of these provisions, see Steve Charnovitz, Exploring the Environmental Exceptions of GATT Article XX, $25 \mathrm{~J}$. WORLD TRADE, Oct. 1991 , at $37-47$.

176. United States-Imports of Certain Automotive Spring Assemblies, GATT B.I.S.D. (30th Supp.) at 107-28 (1984).

177. Id. III $1,6,14$. 
the exclusion order met the necessary standard under the Article XX(d) exception and met the terms of the chapeau. ${ }^{178}$ Therefore, no violation was found.

In the Tuna-Dolphin cases, the two panels held that the PPM-based import bans did not qualify for an Article XX exception. Both decisions were popular among most WTO governments, and both were opposed by the United States. Neither decision was adopted.

The first Tuna-Dolphin decision (1991) focused on an import ban on tuna from Mexico. The panel asserted that Article XX(b) did not cover such an "extrajurisdictional" measure to safeguard dolphins outside the United States. ${ }^{179}$ According to the panel, if Article XX(b) were applied in this way, the importing government "could unilaterally determine the life or health protection policies from which other contracting parties could not deviate without jeopardizing their rights under the General Agreement.",180

The second decision (1994) honed in on the intermediary import ban of tuna from certain European countries. ${ }^{181}$ This tuna was being barred because the so-called intermediary governments had not prohibited the importation of tuna from Mexico (and other primary targets of the U.S. regulation). ${ }^{182}$ As the U.S. import ban was predicated on the foreign law, it was a government policy standard. The panel pointed out that tuna imports were prohibited "whether or not the particular tuna was harvested in a manner that harmed or could harm dolphins." 183 The primary embargo had the same fault, said the panel, and both types of embargo "were taken so as to force other countries to change their policies with respect to persons and things within their own jurisdiction."184 The panel then said that Article XX(g) did not permit such a measure because if it did, "the balance of rights and obligations among contracting parties, in particular the right of access to markets, would be seriously impaired."185 Furthermore, in describing the task before it, the panel said that it

had to resolve whether the contracting parties, by agreeing to give each other in Article $\mathrm{XX}$ the right to take trade measures necessary to protect the health and life of plants, animals and persons or aimed at the conservation of exhaustible natural resources, had agreed to accord each other the right to impose trade embargoes for such purposes. ${ }^{186}$

The panel assumed that an exporting country has a "right of access" to the U.S. market, and that this right has independent valence in the implementation of Article XX. Furthermore, the panel made the assumption

178. Id. . 55-56, 59-61. The text of Article XX(d) is provided in supra note 99.

179. Tuna-Dolphin I Report, supra note 129 , I 5.27. The panel made a similar ruling regarding Article XX(g). Id. ๆ 5.32.

180. Id. If 5.27 (emphasis added). As some commentators noted at the time, this point was circular since Mexico's rights to have its tuna accepted by the United States could not be determined independently of application of Article XX.

181. Tuna-Dolphin II Report, supra note 141, q耳5.23, 5.36.

182. Id. ๆ 5.5 .

183. Id. 15.23 .

184. Id. I 5.24. The panel uses the term "countries" as a synonym for governments.

185. Id. $\ 5.26$.

186. Id. \ 5.42 (emphasis added). 
that in the pre-GATT period, states lacked a right to use trade embargoes for health and conservation purposes and that the GATT had omitted to accord such rights to them. The rejoinder is that such rights are inherent to sovereignty and that the governments writing the GATT did not relinquish them. As Richard J. McLaughlin has pointed out, with Article XX in the GATT, governments "have an expectation that they will be able to restrict trade in order to conserve exhaustible natural resources or to protect the health of humans, animals, and plants."187

The second Tuna-Dolphin panel seemed to be trying to correct the excesses of the first panel, but the second decision was too ambiguous to become the new guidepost. ${ }^{188}$ One GATT commentator, Robert Hudec, read the decision as saying that the U.S. law was a GATT violation because of its coercive design, but that a rewritten law barring imports of fish caught by dolphin-unsafe methods could be justified under Article XX. ${ }^{189}$ Other commentators read the decision as prohibiting PPMs directed at foreign countries. ${ }^{190}$

In the U.S. Automobile Taxes case discussed above, the GATT panel held that the fleet-averaging method could meet the requirements in paragraph (g) of Article XX. ${ }^{191}$ Fleet averaging violated GATT's national treatment discipline because the U.S. regulation was dependent on factors not directly relating to the product. ${ }^{192}$ But Article $\mathrm{XX}(\mathrm{g})$ does not preclude such factors, according to the panel. ${ }^{193}$ In contrast to this favorable holding, the panel found that another feature of the U.S. regulation-separate foreign fleet accounting - prevented the measure from qualifying under Article XX(g). ${ }^{194} \mathrm{In}$ short, the panel ruled that Article XX could potentially permit a producer characteristics PPM, but the GATT Council did not adopt this decision.

In the U.S. Gasoline case, the Appellate Body concluded that the U.S. baseline rule fit within the terms of paragraph $(\mathrm{g})$, but found that the application of the Gasoline regulation violated the Article XX chapeau. ${ }^{195}$ This was the first adopted GATT or WTO decision stating that an environmental PPM could fit within one of the Article XX paragraphs. The measure at issue

187. Richard J. McLaughlin, Sovereignty, Utility, and Fairness: Using U.S. Takings Law to Guide the Evolving Utilitarian Balancing Approach to Global Environmental Disputes in the WTO, 78 OR. L. REV. 855,938 (1999).

188. Cf. Patricia Isela Hansen, Transparency, Standards of Review, and the Use of Trade Measures to Protect the Global Environment, 39 VA. J. INT'L L. 1017, 1032 (1999).

189. Robert E. Hudec, GATT Legal Restraints on the Use of Trade Measures Against Foreign Environmental Practices, in 2 FAIR TRADE AND HARMONIZATION 95, 119, 151 (Jagdish Bhagwati \& Robert E. Hudec eds., 1996).

190. See, e.g., William J. Snape III, Searching for GATT's Environmental Miranda: Are 'Process Standards' Getting 'Due Process?', 27 CORNELL INT'L L.J. 777, 779-81, 785-86, 814-15 (1994).

191. U.S. Automobile Taxes Report, supra note 143, điٔ 5.65-66.

192. See text accompanying supra note 145 .

193. Eric Phillips, World Trade and the Environment: The CAFE Case, 17 Mich. J. INT'L L. 827,850 (1996).

194. U.S. Automobile Taxes Report, supra note 143, $\$ 5.49$.

195. Appellate Body Gasoline Report, supra note 100, at 13-29. 
was a producer characteristics PPM. ${ }^{196}$ The marketability of the gasoline depended on the foreign or domestic status of the producer and on achieving reductions from an assigned baseline. ${ }^{197}$

In complying with the WTO decision, the U.S. government changed its regulation to allow foreign refiners the option of applying for and using an individual baseline. ${ }^{198}$ The ability to sell gasoline is still based on producer characteristics, but the blatant discrimination against foreign producers was removed. To assure compliance, foreign refiners had to agree to a set of enforcement measures including unannounced inspections by U.S. regulators. Under the new regulation, the ability to sell a particular gallon of gasoline depends on whether the producer has met its baseline requirements. Thus, gasoline from one producer could be barred while identical gasoline from another producer is permitted.

The Shrimp-Turtle case involved an import ban on shrimp from countries that did not have a turtle-conservation regime comparable to that of the United States. ${ }^{199}$ The U.S. law was complex: it blended a government policy standard and a review of the actual performance of the foreign shrimping fleet in safeguarding turtles. ${ }^{200}$ At the time of the panel proceeding, the first three of the complaining countries were under a shrimp embargo linked to a requirement that they enforce comprehensive regulations regarding the use of turtle excluder devices by their fishing vessels. ${ }^{201}$ Thus, in this adjudication, the U.S. measure was framed as a government policy standard. ${ }^{202}$

The WTO panel held that the import ban could not be justified by Article XX. ${ }^{203}$ Specifically, the panel declared that the scope of Article XX did not extend to measures that condition market access on the adoption of particular conservation policies by the government seeking access for its nationals. ${ }^{204}$ The panel was troubled by the fact that the U.S. government was requiring the plaintiff governments to adopt prescribed policies for all production, not just for exports to the United States. ${ }^{205}$ The panel found this situation unacceptable because if the United States did this, so could other

196. See supra note 149. It should be noted that none of the parties to the dispute characterized this measure as a PPM.

197. See supra note 150 and accompanying text.

198. Regulation of Fuels and Fuel Additives: Baseline Requirements for Gasoline Produced by Foreign Refiners, 62 Fed. Reg. 45,533 (Aug. 28, 1997). This rule was challenged in U.S. court for several reasons, one of which was that the U.S. Environmental Protection Agency should not have considered U.S. obligations under the WTO in administering the statute. The court upheld the Agency's statutory interpretation and the regulation. Warren Corp. v. EPA, 159 F.3d 616, 624 (D.C. Cir. 1998).

199. United States-Import Prohibition of Certain Shrimp and Shrimp Products, Report of the Panel, WT/DS58/R (May 15, 1998) [herreinafter Shrimp-Turtle Panel Report]. All four of the plaintiff countries had turtle conservation regimes in place. Indeed, two of them (India and Pakistan) had imposed unilateral trade bans on endangered sea turtles before the adoption in 1973 of the Convention on Intemational Trade in Endangered Species of Wild Fauna and Flora (CITES). Id. If 3.4, 3.11.

200. Pub. L. 101-162 § 609(b)(1), (b)(2), 103 Stat. 1038.

201. Shrimp-Turtle Panel Report, supra note $199, \$ 2.16$.

202. Id. I 7.6. The panel noted, however, that the U.S. import ban did not apply to shrimp harvested by aquaculture or in cold water. Id.

203. Id. 77.62 .

204. Id. II $6.6,7.26,7.45,7.50,7.51$.

205. Id. ๆ 7.45 . 
countries, and if these unilateral requirements were inconsistent, "it would be impossible for exporting Members to comply at the same time with multiple conflicting policy requirements." ${ }^{206}$ The panel contrasted such a regulation with a ban on the import of products made by prison labor. ${ }^{207}$ Such a howproduced standard applies only to the products of such labor, not to the exporting country's policy on prison labor. ${ }^{208}$ In summarizing its overall holding, the panel explained that it did "not imply that recourse to unilateral measures is always excluded, particularly after serious attempts have been made to negotiate"209

The Appellate Body upheld the panel's conclusion that the U.S. import ban violated the GATT, but put forward a different reason than the panel. ${ }^{210}$ The Appellate Body found that the import ban did fit within the scope of Article XX and was provisionally justified by XX(g). ${ }^{211}$ Specifically, the Appellate Body stated that the "means and ends relationship" of banning shrimp imports and protecting turtles was "close and real," and the trade measure used was "not disproportionately wide in its scope and reach."12 Nevertheless, the U.S. measure was flawed, the Appellate Body said, because the measure as applied failed to meet the requirements of the Article XX chapeau. ${ }^{213}$ One major flaw was that the U.S. certification process "does not allow for any inquiry into the appropriateness of the regulatory program for the conditions prevailing in those exporting countries."214 Other flaws included inflexibility in administrative determinations and lack of opportunity for the embargoed government to appeal. ${ }^{215}$

To restate the holding, the Appellate Body said that it is not necessarily a GATT violation to impose a government policy PPM on exporting countries but that in doing so the regulator must be sensitive to the conditions in each country, and the administrative process must meet minimum standards of transparency and procedural fairness. This result does not conflict with the GATT Belgian Family Allowances judgment, which was not an Article XX

206. Id. The panel's important point deserves more attention. Suppose that Country A forbids the importation of shrimp from countries that do not require the use of a Turtle Excluder Device (TED) while Country B forbids the importation of shrimp from countries that do not require the use of a Turtle Untrapping Device (TUD). In that hypothetical, no economic actors in Country E would be able to sell simultaneously to buyers in Countries $A$ and $B$. One can make the hypothetical more troublesome by assuming that $A$ is the leading producer of TEDs and $B$ the leading producer of TUDs.

207. Id. ๆ 7.45 n.649.

208. See, e.g., 19 U.S.C. $\S 1307$ (2001) (banning the importation of convict-made goods).

209. Shrimp-Turtle Panel Report, supra note 199, \ 7.61; see also id. 77.56 (noting the possibility that unilateral PPMs would be WTO consistent); David D. Caron \& Hans Rudolf Trüeb, Protecting Trade and Turtles: The WTO and the Coherency of International Law, TRANSLEX, Dec. 1998 , at 3 .

210. Appellate Body Shrimp-Turtle Report, supra note 15.

211. Appellate Body Shrimp-Turtle Report, supra note 15, ff 121, 141, 145, 149. The Appellate Body found that the U.S. measure was made effective in conjunction with a restriction on domestic production (harvesting) of shrimp-that is, the domestic PPM and imported-product PPM were applied evenhandedly. Id. I 144.

212. Id. $₫ 141$.

213. Id. $\mathbb{1} 184$.

214. Id. ๆโ 164-65.

215. Id. ๆๆ 177-82. 
case. But the new ruling shows a sophisticated consideration of discrimination not present in the Family Allowances decision.

The Appellate Body also criticized the United States for not being more cooperative. It noted that the United States was not a party to the United Nations Convention on the Law of the Sea or to the Convention on Biological Diversity, and thus was not making use of existing international cooperative mechanisms. ${ }^{216}$ Furthermore, according to the Appellate Body, the U.S. government had not made serious efforts to negotiate a treaty with affected countries before imposing the import embargo. ${ }^{217}$ The Appellate Body characterized this behavior as unjustified discrimination because the U.S. government had negotiated successfully with other countries seeking to export shrimp to the United States. ${ }^{218}$

Although the Appellate Body did not say that PPMs are legal under the GATT, the inferences in the decision imply the legality of PPMs. ${ }^{219}$ The firstlevel panel had asserted that a shrimp-turtle style of PPM fell outside the scope of Article XX, and the Appellate Body reversed that conclusion. Then the Appellate Body found that the import ban fit paragraph (g), yet failed to comply with the chapeau. Had the Appellate Body believed that the GATT prohibits all non-product-related PPMs, then it could have so stated. The fact that the Appellate Body reviewed the PPM carefully ${ }^{220}$ and gave specific criticisms of how the U.S. government was applying the law demonstrates that PPMs can be justified under Article XX. When the WTO Dispute Settlement Body adopted the Appellate Body report, the delegate from Pakistan (one of the plaintiff governments) recognized the significance of the decision, and stated that, "Effectively, the Appellate Body's decision permitted Members to discriminate against products based on non-product related PPMs."221

In complying with the WTO decision, the U.S. Department of State revised its regulation to accord more due process and provide more flexibility

216. Id. \171.

217. Id. If 166,171 . The U.S. government explained that it attempted to negotiate with the complainant countries after the U.S. court ordered the embargo, but those countries did not respond. Shrimp-Turtle Panel Report, supra note 199, IT 7.54, 7.56.

218. Appellate Body Shrimp-Turtle Report, supra note 15, IT 167, 172, 176.

219. Id. ๆ 121 (stating that it should not be assumed that a measure is incapable of justification under Article XX when the measure requires exporting countries to comply with or adopt specified policies); see Arthur E. Appleton, Shrimp/Turtle: Untangling the Nets, 2 J. INT'L ECON. L. 477, 492 (1999) (stating that under the ruling, measures based on non-product-related PPMs can satisfy Article XX(g)); Howard F. Chang, Toward a Greener GATT: Environmental Trade Measures and the ShrimpTurtle Case, 74 S. CAL. L. REv. 31, 38 (2000) (stating that consistent with the plain language of Article XX, the Appellate Body's opinion allows for import bans designed to change the policies of other governments); Petros C. Mavroidis, Trade and Environment after the "Shrimps-Turtles" Litigation, 34 J. WORLD TRADE, Feb. 2000, at 73, 87 (2000) (stating that unilateral environmental measures are not WTO inconsistent); Scott C. Owen, Might A Future Tuna Embargo Withstand A WTO Challenge in Light of the Recent Shrimp-Turtle Ruling?, 23 Hous. J. INT'L L. 123 (2000) (concluding that it might withstand WTO challenge).

220. According to the Appellate Body, the Article XX chapeau has to be applied "as the kind and the shape of the measures at stake vary and as the facts making up specific cases differ." Appellate Body Shrimp-Turtle Report, supra note 15, $\$ 159$.

221. Dispute Settlement Body, Minutes of Meeting, WT/DSB/M/50, at 5 (Dec. 14, 1998), available at $\mathrm{http}: / / \mathrm{www} . \mathrm{wto} . \mathrm{org}$. 
to foreign governments and to permit shrimp imports so long as the shrimp are harvested under conditions that do not adversely affect sea turtles. ${ }^{222}$ Thus, it became possible under the new regulations for U.S. imports to acquire shrimp from countries that had not received a country-wide certification under the government policy standard. ${ }^{223}$ In effect, this provision carved out a howproduced standard as an alternative to the government policy standard prescribed in U.S. law.

In 2000, the Government of Malaysia complained that the new U.S. regulation did not correct the WTO violation; however, in June 2001 the panel ruled in favor of the United States. ${ }^{224}$ The panel articulated its standard of review to be whether the U.S. government made "serious good faith efforts to negotiate an international agreement, taking into account the situations of the other negotiating countries."225 The panel concluded that the government had made such efforts, and did not analyze the quality of Malaysia's efforts to reach agreement with the United States. In addition, the panel opined that the U.S. trade measures would "be accepted under Article XX if they were allowed under an international agreement," but in the absence of such agreement, such measures are "more to be seen, for the purposes of Article $\mathrm{XX}$, as the possibility to adopt a provisional measure allowed for emergency reasons than as a definitive 'right' to take a permanent measure."'226 Then, building on its new concept of a "provisional" measure, the panel declared that the presence of U.S. compliance "may be reassessed at any time."2227

Malaysia appealed certain elements of the panel's ruling, but the Appellate Body upheld the panel, finding that the United States was in compliance. ${ }^{228}$ The Appellate Body agreed with the panel that the U.S. trade

222. Revised Guidelines for the Implementation of Section 609 of Public Law 101-162 Relating to the Protection of Sea Turtles in Shrimp Trawl Fishing Operations, 64 Fed. Reg. 36,946, 36,949 (July 8, 1999). The regulation stated that the U.S. government would not impose an import ban on shrimp harvested by commercial vessels using turtle excluder devices comparable in effectiveness to those required by the United States.

223. WTO Dispute Panel Report on United States Import Prohibition of Certain Shrimp and Shrimp Products, Recourse to Article 21.5 by Malaysia, WT/DS58/RW, fi 5.107 \& n.232, 5.108 (June 15, 2001), available at http://www.wto.org, [hereinafter Shrimp-Turtle Article 21.5 Panel Report] (noting that U.S. officials had permitted specific shipments of shrimp from Brazil under this provision). The U.S. Court of International Trade has declared this aspect of the regulation to be a violation of U.S. law, but the Court did not enjoin U.S. officials from continuing to provide this flexibility. See Earth Island Institute v. Daley, 48 F. Supp. 2d. 1064 (1999).

224. Shrimp-Turtle Article 21.5 Panel Report, supra note 223, of 153. Article 21.5 is the provision in the DSU that provides for a review as to whether the defendant government has taken measures to comply with an adverse WTO panel report. See DSU, supra note 75, art. 21.5.

225. Shrimp-Turtle Article 21.5 Panel Report, supra note 223, \5.73.

226. Id. If 5.88. The panel's report manifested some discomfort with this finding of U.S. compliance. The panel suggested that if Malaysia sought to export shrimp to the United States,

[I]t would be subject to requirements that may distort Malaysia's priorities in terms of environmental policy. As Article XX of the GATT 1994 has been interpreted by the Appellate Body, the WTO Agreement does not provide for any recourse in the situation Malaysia would face under those circumstances.

Id. 15.103 . The panel then said that the Appellate Body's ruling prevented the panel from finding in favor of Malaysia "on this 'sovereignty' issue. ..." Id.

227. Id. If $5.88,6.1(\mathrm{~b}), 6.2$. Thus, the United States seems to be under a probationary status.

228. WTO Appellate Body Report on United States Import Prohibition of Certain Shrimp and Shrimp Products, Recourse to Article 21.5 by Malaysia, WT/DS58/AB/RW, I 96 (Oct. 22, 2001), 
measure was justified by Article XX so long as the conditions stated in the panel report continued to be satisfied-" in particular the ongoing serious, good faith efforts to reach a multilateral agreement."229 The Appellate Body also agreed that the new U.S. regulation provided sufficient flexibility to foreign governments, and further stated that Article XX does not require an importing government "to anticipate and provide explicitly for the specific conditions prevailing and evolving in every individual [WTO] Member."230

The Appellate Body decision was handed down as this Article was being prepared for publication, and confirms the thesis herein that PPMs do not violate WTO rules. This decision marks the first time that an environmental PPM was declared WTO-compliant. In making its initial decision in ShrimpTurtle in 1998, the Appellate Body assumed, for purposes of its analysis, that the turtles involved traversed U.S. waters. ${ }^{231}$ The issue of what WTO rules dictate concerning PPMs aimed at achieving ecological objectives in the global commons was not reached in this decision. It will take an affirmative judgment in a dispute involving such "extrajurisdictional" conservation to exorcize the demons in the first Tuna-Dolphin decision that so shocked environmentalists in 1991.

The EC Asbestos case does not involve a PPM, but it was the first ruling by a WTO panel that an import measure could be justified by Article XX(b). In applying this exception, the panel held that a health measure could be deemed "necessary" under this provision if there were no other measures consistent (or less inconsistent) with the GATT that could achieve the defendant government's health policy objectives. ${ }^{232}$

The next development in Article XX jurisprudence occurred in the Korea Beef case. ${ }^{233}$ The Australian and U.S. governments complained about a Korean government requirement that foreign beef be segregated and sold separately in Korea..$^{234}$ The WTO panel found this regulation to be a violation of GATT Article III:4. ${ }^{235}$ Reviewing Korea's regulation under Article XX(d), the panel concluded that the dual retail system was a "disproportionate measure not necessary to secure compliance with the Korean law against deceptive practices," and therefore "not justified by Article XX(d) of GATT. "236 Thus, the panel found Korea to be in violation of WTO rules.

available at http://www.wto.org. Australia, India, and Thailand supported Malaysia's position that the U.S. import ban violated WTO rules. Id. of $46,50,64,74$.

229. Id. II 152.

230. Id. \149.

231. Appellate Body Shrimp-Turtle Report, supra note 15, ๆ 133.

232. EC Asbestos Panel Report, supra note 160, If 8.173, 8.179, 8.183, 8.199, 8.204, 8.206. Furthermore, the panel suggests that each government can determine what level of risk it wants to assume. Id. T 8.175 n.119.

233. WTO Appellate Body Report on Korea-Measures Affecting Imports of Fresh, Chilled and Frozen Beef, WT/DS161/AB/R, WT/DS169/AB/R (Dec. 11, 2000), available at http://www.wto.org [hereinafter Appellate Body Korea Beef Report].

234. WTO Dispute Panel Report on Korea-Measures Affecting Imports of Fresh, Chilled and Frozen Beef, WT/DS161/R, WT/DS169/R, I 511 (July 31. 2000), available at http://www.wto.org.

235. Id. If $639,643,692$.

236. Id. ๆ 675 . 
This was not a PPM case, but the Appellate Body's decision has implications for PPM jurisprudence. The Appellate Body upheld the judgment, and established a new balancing interpretation of Article XX(d). ${ }^{237}$ Noting that Article $X X(d)$ requires that measures be "necessary," the Appellate Body held that determining such necessity "involves in every case a process of weighing and balancing a series of factors, which prominently include the contribution made by the compliance measure to the enforcement of the law or regulation at issue, the importance of the common interests or values protected by that law or regulation, and the accompanying impact of the law or regulation on imports or exports." ${ }^{238}$

The Appellate Body cited this Article XX(d) holding in its later decision in the Asbestos appeal. ${ }^{239}$ In the Asbestos case, the Appellate Body upheld the panel's finding that the disputed measure qualified for the Article XX(b) exception. ${ }^{240}$ In reaching that decision, the Appellate Body considered "whether there is an alternative measure that would achieve the same end and that is less restrictive of trade than a prohibition."241 The Appellate Body then examined Canada's proposed alternative and concluded that it would not achieve the same end (that is, the same chosen level of health protection) as the regulatory measure being used by France. ${ }^{242}$ This decision is noteworthy because the Appellate Body incorporated a less-trade-restrictive test into GATT Article XX(b). No previous GATT or WTO panel had done so. ${ }^{243}$ This establishes a new hurdle for governments using an Article XX(b) defense.

In summary, the Article XX exceptions apply to PPMs. ${ }^{24}$ An examination of the GATT and WTO caselaw contradicts the views expressed at the beginning of Part II, all of which came after the Appellate Body decision in the first phase of the Shrimp-Turtle dispute. No adopted GATT or WTO decision has suggested that PPMs are outside the scope of Article XX. ${ }^{245}$ The decisions in the U.S. Gasoline and Shrimp-Turtle cases against

237. Appellate Body Korea Beef Report, supra note 233, qf 164, 186(f).

238. Id. I 164.

239. Appellate Body Asbestos Report, supra note 163, \172.

240. Id. \192(f).

241. Id. \172.

242. Id. โโ] 173-74.

243. For a review of the caselaw, see Axel Desmedt, Proportionality in WTO Law, $4 \mathrm{~J}$. INT'L ECON. L. 441, 460, 462-73 (2001). This test was used in one GATT case regarding Article XX(d) and then resurfaced in the Korea Beef case. Desmedt's article does not draw the conclusion that a less-orleast-trade-restrictive test is a new development in Article XX(b). His Article discusses the development of a proportionality principle in GATT/WTO jurisprudence. In the Shrimp-Turtle compliance decision, the panel suggested that the Appellate Body's Shrimp-Turtle decision of 1998 implied a trade restrictiveness comparison regarding Article XX(g). Shrimp-Turtle Article 21.5 Panel Report, supra note 223, $195.51,5.58,5.67$.

244. Frank Biermann, The Rising Tide of Green Unilateralism in World Trade Law, Potsdam Inst. for Climate Impact Res., PIK REPORT No. 66, at 17 (Dec. 2000), available at http://www.pikpotsdam.de; Sandeep K. Tetarwal \& Pradeep Mehta, Process and Production Methods (PPMs)Implications for Developing Countries, CUTS BRIEFING PAPER No. 7, at 1 (Consumer Unity \& Trade Soc'y 2000).

245. Cf. Jagdish Bhagwati, After Seattle: Free Trade and the WTO, 77 INT'L AFF. 15, 28 (2001) ("I was astounded that the Appellate Court in effect reversed longstanding jurisprudence on PPM (process and production method) in the shrimp-turtle case."). 
environmental measures did not turn on their PPM status. Although the Shrimp-Turtle panel criticized the coerciveness of a government policy standard, the Appellate Body did not perceive the use of PPMs as legally fatal. None of the GATT/WTO environmental cases has involved a how-produced standard.

As noted above, the Appellate Body has endorsed balancing to some extent in two recent Article XX decisions. This new development is troubling because the WTO has no institutional competence for weighing incommensurate values, such as the exporting interests of one country against the environmental interests of another ${ }^{246}$ A few years ago, Thomas Schoenbaum observed that

[E]nforcement of PPMs in other countries could be encouraged by replacing the current legal tests with a more lenient test that would allow WTO dispute settlement panels to balance the legitimacy of the protected environmental value with the disruption to trading interests. This proposal, which is derived from the way the United States Supreme Court decides Commerce Clause cases, seems unsuited to international tribunals like WTO panels whose ad hoc judges would thereby be delegated extraordinary discretion. ${ }^{247}$

Leaving aside the questionable proposition that balancing will be a "more lenient" approach to PPMs, Schoenbaum is right that such balancing is unsuited for dispute resolution under the trading system. Balancing is inappropriate because there is no way for a panel to objectively weigh incommensurate concerns, such as the value of commercial freedom versus the value of environmental protection, where the litigant governments will likely have different metrics for these values. The problem is not just that balancing by trade experts will tend to value trade more than environment. Rather, the problem is one of legitimacy. WTO governments show no willingness to delegate basic policy judgments to independent panels.

\section{E. Restatement of the Law}

For environmental PPMs, the most important WTO law is found in GATT Article XX and can be restated as follows: The WTO/GATT does not prohibit environmental PPMs as such. PPM-based import bans may be inconsistent with GATT Articles I, III, or XI, yet if undertaken for an environmental purpose, such measures still may qualify for an Article XX exception. Both the government policy standard and the producer characteristics standard are potentially justifiable under Article XX, but both standards will receive scrutiny as to procedural fairness and environmental

246. For example, suppose that the United States bans all shrimp from Malaysia because of one turtle death there. A reasonable person might say that the U.S. action values turtles over trade. On the other hand, suppose that Malaysia refuses to spend $\$ 30,000$ to save hundreds of turtles. A reasonable person might say that Malaysia overvalues exports over turtles. These would be easy cases for a WTO panel engaged in balancing, but one can imagine more difficult ones. By what metric is the WTO panel supposed to make such judgments?

247. Thomas J. Schoenbaum, International Trade and Protection of the Environment: The Continuing Search for Reconciliation, 91 AM. J. INT'L L. 268, 291 (1997) (citations omitted). 
justification. A how-produced standard might be subject to less scrutiny because its means are more clearly related to its policy ends.

In its first two Article XX environmental decisions (U.S. Gasoline and Shrimp-Turtle), the Appellate Body breathed life into the Article XX chapeau, which can serve as a bulwark against unfair and protectionist measures. ${ }^{248}$ By contrast, the chapeau played no part in the Tuna-Dolphin reports. The rigorous chapeau review in Shrimp-Turtle may develop as a key foundation of the new law of PPMs.

\section{F. Broader Implications}

This Article has focused on environmental PPMs, but the question arises whether the same conclusion - that the WTO does not prohibit environmental PPMs - applies to other kinds of PPMs. For example, what would be the legal status of an import ban on apparel made by exploited children, or on fur from a country that permits leg-hold traps, or on pharmaceuticals tested on animals? ? $^{249}$ For such issues, no authoritative answer exists as of yet. In Shrimp-Turtle, the Appellate Body saw a "nexus" between the locus of the environmentally-harmful shrimping and the U.S. interest in conserving migratory sea turtles. ${ }^{250}$ Such a nexus should be easy to find where the dispute involves an ecosystem shared by the litigant countries. But for social or moral issues, the required nexus may not exist. Furthermore, the Appellate Body found that the U.S. trade measure on shrimp was "reasonably related to the ends" of conserving an endangered species. ${ }^{251}$ Non-environmental PPMs would be subject to analogous scrutiny as to whether the means relate reasonably to the ends. The Appellate Body also stated that the "actual contours and contents" of the Article XX chapeau will vary "as the kind of measure under examination varies." 252

It should also be noted that PPMs address only one part of the product cycle, and the legal conclusions presented here might not be applicable to regulations that extend beyond production. Importation can be made contingent on a variety of post-production practices. For example, goods that are stolen, mislabeled, or packaged in certain ways might be stopped at the border. Similarly, importation can be contingent on how a product is to be used or what disposal methods are readily available. ${ }^{253}$ Importation can also be

248. Appellate Body ${ }^{\circ}$ Shrimp-Turtle Report, supra note 15, ๆ 160 (noting that the chapeau projects both substantive and procedural requirements); Chang, supra note 17, at 2172, 2208 (noting that the Article XX chapeau contains clauses designed to prevent abuse of the exceptions).

249. See, e.g., RoYal Society FOR THE PREVENTION OF CRUELTY TO ANIMALS, WTO-Food FOR THOUGHT-FARM ANMAL WeLfARE AND THE WTO (1999); Adelle Blackett, Whither Social Clause? Human Rights, Trade Theory and Treaty Interpretation, 31 CoLUM. HuM. RTS. L. REv. 1 (1999). In November 2000, the U.S. government banned clothing imports from a factory in Mongolia after finding that the factory employed underage children on long shifts. Joseph Kahn, Citing Child Labor, U.S. Bans Apparel From Mongolia Plant, N.Y. Times, Nov. 29, 2000, at C6.

250. Appellate Body Shrimp-Turtle Report, supra note 15, I 133.

251. Id. ๆ 141.

252. Id. ๆ 120.

253. For example, in the United States, there is a high tariff on hand-woven wool fabrics, but this tariff is omitted when such fabrics are to be used or sold by a religious institution. United States 
contingent on whether exportation is legal in the country of export. ${ }^{254}$ Note that the common feature in all of these requirements is that two otherwise like products are treated differently.

Although this Article addresses only regulations imposed on imports, many of the same legal issues arise in export restrictions. For instance, the U.S. government is a prodigious user of technology-export controls that treat like products differently depending upon how the product is to be used, who the end user is, and where the end use will be. ${ }^{25 s}$ Unilateral controls that involve military equipment may be justified by GATT Article XXI (security exceptions), which provides an exception for traffic in "goods and materials as is carried on directly or indirectly for the purpose of supplying a military establishment."256 The North American Free Trade Agreement (NAFTA) provides a good example of an export restriction linked to where a product is to be used. The Energy Chapter states that NAFTA parties may, in exporting an energy product or a petrochemical good to a party, require that the energy product be consumed in that party's territory rather than be re-exported to another country. ${ }^{257}$

To summarize, Part III explicates the WTO law of PPMs and demonstrates the falsity of the myth that PPMs are illegal under the WTO. This is a significant finding since, as Part I explains, PPMs are sometimes needed for environmental policymaking. The last part of the Article will discuss how a better appreciation of WTO law can help governments make progress in resolving tensions between trade and environmental interests.

\section{DEBUNKING THE MYTH AND MOVING FORWARD}

The argument that environmental PPMs violate the WTO has not had its intended effect. Rather than inhibiting PPMs, it has prevented a reasoned discourse about how to distinguish appropriate from inappropriate PPMs. Little is being done to deal with the root causes of such trade restrictions.

When negotiators do not share a common legal understanding about the subject of a negotiation, a successful resolution will be difficult to achieve. It is hard to bargain in the shadow of the law when governments have sharply divergent views on what the law is. Because the governments most opposed to PPMs believe (incorrectly) that they are illegal, they have adopted an implacable and adversarial stance toward PPMs that has undermined any resolution of the conflict.

International Trade Commission, Harmonized Tariff Schedule of the United States, subheading 9810.00.20, available at http://dataweb.usitc.gov/SCRIPTS/tariff/toc.html (last visited Aug. 24, 2001).

254. For example, U.S. law bans the import of fish or wildlife transported or sold in violation of any foreign law. 16 U.S.C. $\$ 3372(a)(2)(A)(1994)$. 2000).

255. See generally COPING WTH U.S. EXPORT CONTROLS (Evan R. Berlack \& Cecil Hunt eds.,

256. GATT art. XXI(b)(ii), supra note 3.

257. North American Free Trade Agreement, Dec. 17, 1992, art. 603.3(b), 32 I.L.M. 289, 365

(1993) (applying when a party maintains a restriction on exportation of an energy product to a nonparty). 
But it is not just opponents of PPMs who are victims of the myth that PPMs are illegal. Some of the people who recognize the need for PPMs are also confused about WTO law. Therefore, these individuals and groups tend to frame their proposals as amending the WTO to permit certain kinds of PPMs. ${ }^{258}$ Yet because WTO decisionmaking is consensual, such action will be impossible, and the lack of movement at the WTO reinforces the perception that "trade and environment" issues are irresolvable. ${ }^{259}$

The continuing debate about the status of PPMs erodes support for the WTO. Developing country officials, who may believe the myth that the WTO prohibits PPMs, perceive the continued use of PPMs by the United States as proof that the WTO remains power-based rather than rule-based. ${ }^{260}$ Conversely, proponents of environmental PPMs worry that the WTO will attack such measures. ${ }^{261}$ This has detrimental effects for the trading system, since alienated environmentalists will undermine public support for the WTO. Moreover, the schism between environmentalists and the trading system is also bad for environmental policy. Until the status of PPMs is properly understood, many environmentalists are not going to pay much attention to the ways in which WTO rules and trade itself can promote opportunities for better environmental policy. Therefore, win-win opportunities are being missed. ${ }^{262}$

If stakeholders shared a common understanding of the WTO law of PPMs, it might be possible to begin to bridge the gap between commerce and conservation. The proponents of PPMs should admit that they sometimes impose disproportionate costs on particular countries, and the opponents should admit that PPMs sometimes generate global benefits. When a foreign practice has an adverse environmental impact at home, the WTO should not demand that citizen-consumers accept foreign products of that process in the interest of promoting greater trade. What the WTO can do, however, is to erect effective disciplines for assuring that PPMs have an environmental justification and are applied in a justifiable manner. ${ }^{263}$ The next two sections make suggestions for disciplining and managing PPMs. Disciplines are

258. Aaron Cosbey, Institutional Challenges and Opportunities in Environmentally Sound Trade Expansion: A Review of the Global State of Affairs, in NORTH-SOUTH AGENDA PAPERS No. 41, at 3-5 (North-South Ctr. 2000), available at http://www.miami.edu/nsc (proposing a new WTO agreement to address PPMs and environmental treaties); see also Sarah H. Cleveland, Norm Internalization and U.S. Economic Sanctions, 26 YALE J. INT'L L. 1, 65-66 (2001) (noting that the trade law decisions regarding tuna, shrimp, and bananas have increased pressure from industrial countries, and particularly from labor and environmental groups, to loosen GATT restrictions in order to accommodate domestic legislation promoting valid public policy concerns).

259. See WTO Agreement, supra note 3, art. IX:1 (decisionmaking by consensus); Malaysia Against Any Move to Amend Existing GATT/WTO, XINHUA ENGLISH NEwSWIRE, June 9, 1998, LEXIS NEXIS Library Newsgroup file (discussing the use of trade measures to address environmental problems).

260. Based on the reaction of government delegates to the WTO during the author's lecture on the topic presented in this Article in October 2000.

261. See Peter fugazzotto \& Todd Steiner, Slain By Trade: The Attack of the World TRAde ORganization ON SEA TURTLES AND THE US ENDANGERED SPECIES ACT (1998).

262. SAMPSON, supra note 1, at 50-53 (discussing win-win scenarios).

263. Figueres Olsen, Salazar-Xirinachs \& Araya, supra note 91, at 175 (stating that a creative approach would be an international system that identifies the appropriate baseline standards and punishes unfair PPM-based discrimination). 
needed to screen out improper PPMs that are unfair to exporting countries, particularly developing countries. Better global management is needed to resolve the transborder problems that give rise to PPMs.

\section{A. Disciplining PPMs}

Disciplines are needed against ill-conceived environmental PPMs applied to imports. International rules should strongly discourage PPMs that prescribe inappropriate policies for foreign countries, or those that are implemented unfairly. Much of what ought to be done lies within the competence of the trade regime. But complementary action in other regimes will also be required.

Although many commentators claim that the key distinction is that of multilateral versus unilateral PPMs, the reality is more complex, with many different shades of multilateralism. A treaty can require a PPM-for example, the Montreal Protocol on Ozone forbids the importation of controlled substances from States that are not party to the Protocol (or have not agreed to be bound by it) ${ }^{264} \mathrm{~A}$ treaty can authorize a PPM-for example, the Wellington Convention on Driftnets states that each Party may take measures consistent with international law to prohibit the importation of fish caught using a driftnet. ${ }^{265} \mathrm{~A}$ treaty can authorize trade measures in response to actions that undermine the treaty-for example, the Anadromous Stocks Convention directs the Parties to take appropriate measures to prevent trafficking in anadromous fish taken in violation of the Convention. ${ }^{266}$ Furthermore, the Commission administering an environmental treaty can authorize nonproduct-related PPMs. For example, on several occasions the International Commission for the Conservation of Atlantic Tunas has recommended that Parties take "non-discriminatory trade restrictive measures" on specified fishery products from listed countries that are adjudged to be violating the Convention. ${ }^{267}$ While all of these examples might be called multilateral, they are also unilateral (except for the Montreal Protocol) because the PPM-using country is encouraged but not required to use the trade measure. Moreover, under some of the treaties, the trade action is (or can be) directed at nonparties, so it is not consensually based.

Despite these complexities, the degree of multilateral approval for the PPM ought to be a factor in evaluating its appropriateness. If several countries are applying the PPM, then it is much less likely to be protectionist or arbitrary. This factor can also be expressed as multilateral disapproval. A

264. Montreal Protocol on Substances that Deplete the Ozone Layer, supra note 62, arts. 4.1, 4.9. This is a government policy standard.

265. Convention for the Prohibition of Fishing with Long Driftnets in the South Pacific, Nov. 24, 1989, 29 I.L.M 1454, art. 3(2). This is a how-produced standard.

266. Convention for the Conservation of Anadromous Stocks in the North Pacific Ocean, Feb. 11, 1992, U.S. Senate Treaty Doc. 102-30, art. III:3, available at http://www.npafc.org.

267. See, e.g., Resolution by ICCAT Concerning an Action Plan to Ensure Effectiveness of the Conservation Program for Atlantic Bluefin Tuna, transmitted Jan. 23, 1995, available at http://www.iccatorg. 
treaty can admonish against a unilateral trade ban or even preempt it. ${ }^{268}$ For example, the Inter-American Convention for the Protection and Conservation of Sea Turtles directs parties to act in accordance with GATT Article XI with respect to the subject matter of the Convention. ${ }^{269}$ This seems to imply no import bans since Article XX is not mentioned.

When unilateral PPMs are under review, GATT Article XX will often be the decisive law. If product $Y$ is banned to safeguard a resource $Z$, the WTO will need to analyze the facts underlying the relationship between $\mathrm{Y}$ and $\mathrm{Z}$. For instance, in the Shrimp-Turtle case, the Appellate Body considered shrimping regulation, turtle conservation, and how shrimping affected turtles. ${ }^{270}$

To scrutinize PPMs, the WTO will assess the validity of the environmental purpose underlying the trade measure. This may proceed with some deference, however. As the Appellate Body pointed out in the U.S. Gasoline case, WTO Member governments retain "a large measure of autonomy to determine their own policies on the environment."271 The Appellate Body also stated that Article XX decisions need to be made on a case-by-case basis. ${ }^{272}$

In judging PPMs, the WTO should not tolerate an economic motivation for imposing a PPM on imports. ${ }^{273}$ For example, it is one thing for the United States to demand that the shrimp it imports be caught in a turtle-safe way so as to safeguard turtles. Yet it is an entirely different matter to seek to "level the playing field" by insisting that foreign producers use the same production practice as U.S. shrimpers so as to offset any regulatory cost differences between domestic and foreign producers. This latter motivation should not be shielded by GATT Article XX. ${ }^{274}$

The WTO should discourage the most troublesome types of PPM. The government policy standard should be disfavored because it is coercive and abides origin-based discrimination. ${ }^{275}$ The producer characteristics standard

268. See Robert Howse, Managing the Interface between International Trade Law and the Regulatory State: What Lessons Should (and Should Not) Be Drawn from the Jurisprudence of the United States Dormant Commerce Clause, in REgUlatory BARRIERS AND THE PRINCIPLE OF NoNDisCRIMINATION IN WORLD TRADE LAW, supra note 38, at 139, 151.

269. Inter-American Convention for the Protection and Conservation of Sea Turtles, supra note 59, art. XV:2; Appellate Body Shrimp-Turtle Report, supra note 15, 1170.

270. Appeliate Body Shrimp-Turtle Report, supra note 15, fi 135, 138, 140-41, 186.

271. Appellate Body Gasoline Report, supra note 100, at 30.

272. Id. at 18 .

273. See Frederic L. Kirgis, Jr., Effective Pollution Control in Industrialized Countries: International Economic Disincentives, Policy Responses, and the GATT, 70 MiCH. L. REV. 859, 901-02 (1972).

274. See Jagdish Bhagwati \& T.N. Srinivasan, Trade and the Environment: Does Environmental Diversity Detract from the Case for Free Trade?, in 1 FAIR TRADE AND HARMONIZATION 159-99 (Jagdish Bhagwati \& Robert E. Hudec eds., 1996).

275. It is interesting to note that the WTO Agreement on Textiles and Clothing commits governments to take action against transshipment of goods from the country of origin through another country. In particular, the Agreement authorizes the use of import restraints against foreign countries "where there is evidence of the involvement of the territories of the Members through which the goods have been transshipped." Agreement on Textiles and Clothing, supra note 71, art. 5.4. Such an import restraint would be a government policy PPM because the import ban would be linked to whether the 
should be disfavored because such a standard is too easy to tilt against foreign producers. Thus, if a unilateral PPM is to be used, it should be crafted as a how-produced standard that can be aimed directly at the odious production practice. When possible, the standard should be expressed flexibly in terms of performance rather than design. ${ }^{276}$ In other words, rather than specifying a type of turtle-excluder device, the importing government might set a maximum tolerance for incidental turtle deaths during shrimping. This could be policed by observers and product certifications.

In calling for a disfavoring of the government policy standard, this Article is not calling for it to be outlawed. There may be circumstances when a how-produced standard is impractical. For example, when raw materials are co-mingled in production, there may be no way to enforce a how-produced PPM. A how-produced standard may also prove to be unsuccessful. One can easily imagine a scenario where the how-produced standard does not prevent the environmental damage but instead only reallocates the product to different markets. ${ }^{27}$ For example, in a dispute like Shrimp-Turtle, the turtle-safe shrimp could be shipped to countries that insist on it while the more haphazardlycaught shrimp is shipped elsewhere (perhaps at a lower price).

In addition to examining the PPM itself, the WTO should also examine why it is invoked and how it is applied. The first Appellate Body decision in the Shrimp-Turtle case lays down helpful markers for steps that should be taken to pursue multilateral cooperation and to accord due process to the exporting country. ${ }^{278}$ Some commentators have been critical of these points, particularly as they relate to international negotiations. For example, Lakshman Guruswamy contends that the Shrimp-Turtle decision "constitutes a violation of the principle of state sovereignty by attempting to second-guess the manner in which the United States should have conducted treaty negotiations. ${ }^{\text {'279 }}$ Virginia Dailey argues that the language of Article XX should not be interpreted to require governments to attempt to negotiate a treaty as a precondition for using a trade measure. ${ }^{280} \mathrm{John} \mathrm{O}$. McGinnis and Mark L. Movsesian argue that the WTO should not establish a duty to negotiate because that "would require the Appellate Body to make sensitive judgments about the desirability of various regulatory options and thereby inexorably move it toward shaping international standards."281 These commentators are

exporting government has a policy of prohibiting transshipment.

276. See TBT Agreement, supra note 12, art. 2.8 (directing governments to use performance rather than design-based regulations wherever appropriate). In October 2001, the Government of New Zealand proposed a set of "Environment and Trade Principles" for the forthcoming WTO Ministerial in Doha. One principle is that governments should "seek standards that focus on the environmental objective which is being promoted, rather than seek to prescribe unnecessarily the method by which the objective should be reached." Press Release, The Honorable Jim Sutton, Government Issues New Trade and Environment Framework (Oct. 25, 2001), available at http://www.executive.govt.nz.

277. Chang, supra note 17, at 2179.

278. See supra text accompanying notes 214-218.

279. Lakshman Guruswamy, The Annihilation of Sea Turtles: World Trade Organization Intransigence and U.S. Equivocation, 30 ENVTL. L. REP. 10,261, 10,267 (2000).

280. Virginia Dailey, Sustainable Development: Reevaluating the Trade vs. Turtles Conflict at the WTO, 9 J. TRANSNAT'L L. \& POL'Y 331, 377 (2000).

281. John O. McGinnis \& Mark L. Movsesian, The World Trade Constitution, 114 HARv. L. 
right to flag this issue, but their conclusions may be going too far. Prior efforts to negotiate a treaty can be relevant to Article XX review in order to see whether unilateralism is justified. Moreover, it is not clear whether the Appellate Body is suggesting a general duty to negotiate or, more narrowly, a duty to avoid discrimination in negotiations.

Although better disciplines for PPMs can emerge through WTO adjudication, some of the criteria suggested here are not in GATT Article XX and should not be read into it. Thus, rather than relying on evolutionary interpretation, it would be better for the WTO to negotiate new rules so that all governments could participate in this exercise. Moreover, the opportunities for lawmaking through interpretation are limited by the content and flow of the cases. Such negotiations could bring to bear other solutions-for example, capacity building for environmental management-that would require action outside the WTO. Achieving this result need not require any change in Article XX itself. Rather, governments could negotiate an Understanding on Article XX analogous to the seven GATT Understandings negotiated during the Uruguay Round.

\section{B. Improving WTO Management of PPMS}

To improve management of PPMs, the following steps should be taken. First, the WTO should promote greater transparency of PPMs. This might be done through the Trade Policy Review Mechanism (or through another WTO subsidiary body) with input from relevant international organizations. ${ }^{282} \mathrm{~A}$ WTO review of a particular PPM-written outside the context of dispute settlement-might give some impetus to self-examination by the demandeur government. One should not assume that the only way to get a government's attention is to convict it of a WTO violation.

Second, a new trade and environment conflict is a signal of inadequate international environmental cooperation, and that signal should be transmitted into a recommendation by the WTO to appropriate multilateral environmental institutions. The Tuna-Dolphin I panel said that the negotiation of international cooperative arrangements for dolphin protection "would seem to be desirable in view of the fact that dolphins roam the waters of many states and the high seas." 283 The Shrimp-Turtle panel said that "the best way for the parties to this dispute to contribute effectively to the protection of sea turtles in a manner consistent with WTO objectives, including sustainable development, would be to reach cooperative agreements on integrated conservation strategies."284 The Appellate Body in the Shrimp-Turtle case said that governments should act together "bilaterally, plurilaterally and multilaterally, either within the WTO or in other international fora, to protect

\footnotetext{
REV. 511,593 (2000).

282. See Trade Policy Review Mechanism, Apr. 15, 1994, WTO Agreement, Annex 3, LEGAL TEXTS, supra note 3 , at 380 .

283. Tuna Dolphin I Report, supra note 129, I 5.28.

284. Shrimp-Turtle Panel Report, supra note 199, I9.1 (citation omitted).
} 
endangered species or to otherwise protect the environment. ${ }^{9285}$ But neither the GATT nor the WTO acted on these observations by communicating a recommendation to a sister international agency.

Third, the WTO should make it easier for developing countries to comply with PPMs. The WTO might begin by holding hearings to investigate the costs of controversial PPMs. The hearings could bring to light less expensive ways to achieve the intended environmental purpose. At such hearings, the government using the PPM might be asked what financial or technological assistance it is making available to the adversely affected countries. The WTO treaty contains some imprecise obligations regarding assistance to developing countries that could serve as a basis for such an examination. For example, the TBT Agreement directs governments to "take account of the special development, financial and trade needs" of developing countries with a view toward ensuring that regulations "do not create unnecessary obstacles to exports from developing country Members. ${ }^{3286}$ The TRIPS Agreement directs industrial countries to "provide incentives to enterprises and institutions in their territories for the purpose of promoting and encouraging technology transfer" to less developed countries. ${ }^{287}$ These provisions may be too vague to be enforced through dispute settlement, but they are specific enough for governments to inquire about implementation.

Fourth, the WTO needs to clarify that its disciplines do not prohibit process-related mandatory labeling. ${ }^{288}$ PPM labeling offers a potential avenue to avoid trade restrictions by leaving the choice to consumers. ${ }^{289}$ This is a market friendly response, and truthful labels should not be discouraged by the WTO. ${ }^{290}$

Finally, although the above steps would help, new trade and environment disputes are inevitable. When they occur, the WTO DirectorGeneral should be more active in offering mediation and conciliation services. ${ }^{291}$ In some cases, like Shrimp-Turtle, both sides were partly right and

285. Appellate Body Shrimp-Turtle Report, supra note 15, at \ 185.

286. TBT Agreement, supra note 12, art. 12.3.

287. TRIPS Agreement, supra note 13, art. 66.2.

288. The only trade case to address labeling was Tuna Dolphin I, which considered the U.S. criteria for access to a "dolphin-safe" label. The panel found that since tuna could be sold in the United States with or without the label, the U.S. law did not violate GATT Article I. Tuna-Dolphin I Report, supra note 129 , II $5.41-44$. The panel's decision offers no guidance as to whether a law requiring that all tuna be labeled as to its dolphin safety or non-safety would violate WTO rules.

289. Of course, a consumer may want to free ride by buying the less expensive product without the label. So a label alone may not be an optimal response to economic externalities. Chang, supra note 17, at 2177; Howse \& Regan, supra note 44, at 273.

290. See ESTY, supra note 1, at 283 (indicating with matrix when labeling is the appropriate instrument); Doaa Abdel Motaal, The Agreement on Technical Barriers to Trade, The Committee on Trade and Environment, and Eco-Labelling, in TRADE, ENVIRONMENT, AND THE MILLENNIUM, supra note 1, at 223; Geert van Calster, The EU, Trade, Environment and Unilateralism: Passing the Buck, 5 EUR. FOREIGN AFF. REv. 2-25 (2000) (discussing WTO law on labeling). Labeling is also controversial on issues beyond the environment. See, e.g., Janet Hilowitz, Social Labelling to Combat Child Labour: Some Considerations, 136 INT'L LAB. Rev. 215 (1997); Daniel Pruzin, Developing Countries Hit Out at Belgian "Labor Label" at WTO, BNA DAILY REP. FOR EXECUTIVES, Apr. 2, 2001, at A-6.

291. See DSU, supra note 75, art. 5.6; Yuji Iwasawa, Settlement of Disputes Concerning the WTO Agreement: Various Means Other Than Panel Procedures, in TRILATERAL PERSPECTIVES ON 
partly wrong. That dispute should have been settled (or prevented) with the United States giving help to the complaining countries to improve shrimping practices. Another idea-suggested by Gabrielle Marceau-is for the WTO to establish an Environmental Advisory Body. This Body would seek a solution to trade and environment conflicts short of formal dispute settlement. ${ }^{292}$ The composition of such a Body could include experts from industry and nongovernmental organizations.

\section{CONCLUSION}

As highlighted in the October 2001 Appellate Body decision in ShrimpTurtle, an environmental PPM is not illegal under WTO rules. Whenever it violates GATT Articles I, III, or XI, a PPM will be reviewed under GATT Article XX(b) or $(\mathrm{g})$ and the chapeau to the Article. With respect to the chapeau, the Appellate Body has explained that the line of legality "moves as the kind and the shape of the measures at stake vary and as the facts making up specific cases differ." ${ }^{\text {"293 }}$ Thus, the WTO legality of a PPM will depend both on its environmental rationale and on its implementation.

By debunking the myth that PPMs are illegal and by exploring why they are used, this Article develops a new approach to the PPM problem that views PPMs as a symptom of governance dysfunction. To remedy this dysfunction, policymakers should address the root causes of conflict. Sometimes governments use PPMs because that is the only way to respond to a global or transborder environmental harm occurring in another country. In those situations, the right role for the WTO may be to stand aside. ${ }^{294}$ Sometimes governments use PPMs to counter a loss of competitiveness arising out of domestic regulation. In those situations, the right role for the WTO may be to seek withdrawal of the PPM. Outside the WTO, there will be a need for international environmental institutions to step in with technical assistance and other efforts to spur environmental cooperation. With proper oversight by the WTO, PPMs may help solve the problems that elicit their use by catalyzing governments to improve environmental policy.

INTERNATIONAL LEGAL ISSUES: RELEVANCE OF DOMESTIC LAW AND POLICY 377, 384-86 (Michael K. Young \& Yuji Iwasawa eds., 1999) (discussing the "good offices" of the Director-General); Daniel Pruzin, Moore Urges Members to Consider Mediation Option at WTO Dispute Settlement, BNA DAILY REP. FOR EXECUTIVES, June 21, 2001, at A22.

292. Gabrielle Marceau, A Call for Coherence in International Law. Praises for the Prohibition Against "Clinical Isolation" in WTO Dispute Settlement, 33 J. WORLD TRADE, Oct. 1999, at $87,148-49$.

293. Appellate Body Shrimp-Turtle Report, supra note 15 \ा 159.

294. Richard W. Parker, The Use and Abuse of Trade Leverage to Protect the Global Commons: What We Can Learn From the Tuna-Dolphin Conflict, 12 GEO. INT'L ENVTL. L. REV. 1, 117 (1999). 